Lee, J.R., Phillips, E., Booth, S.J., Rose, J., Jordan, H.M., Pawley, S.M., Warren, M., Lawley, R.S. 2013. A polyphase glacitectonic model for ice-marginal retreat and terminal moraine development: the Middle Pleistocene British Ice Sheet, northern Norfolk, UK. Proceedings of the Geologists' Association, 124, 753-777. PRE-PROOF ACCEPTEF MANUSCRIPT.

\title{
A polyphase glacitectonic model for ice-marginal retreat and terminal moraine development: the Middle Pleistocene British Ice Sheet, northern Norfolk, UK
}

\author{
Jonathan R. Lee ${ }^{1,2}$, Emrys Phillips ${ }^{3}$, Stephen J. Booth ${ }^{1,2}$, James Rose ${ }^{2,1}$, Hannah \\ M. Jordan ${ }^{1}$, Steven M. Pawley ${ }^{2}$, Martin Warren ${ }^{4}$, Russell S. Lawley ${ }^{1}$ \\ ${ }^{1}$ British Geological Survey, Keyworth, Nottingham, NG12 5GG, UK. \\ ${ }^{2}$ Department of Geography, Royal Holloway University of London, Egham, Surrey, TW20 OEX, UK. \\ ${ }^{3}$ British Geological Survey, Murchison House, West Mains Road, Edinburgh, EH9 3LA, UK. \\ ${ }^{4}$ The Northfolk Project, Chesterfield Lodge, West Street, Cromer, Norfolk, NR27 9DT, UK. \\ *Corresponding Author: jrlee@bgs.ac.uk
}

Keywords: glacitectonic; terminal moraine; active retreat; Cromer Ridge; thin-skinned; East Anglia

\begin{abstract}
Recent investigations from modern environments demonstrate that many terminal moraines do not simply record a single glacial maximum, but instead reveal a complex pattern of ice-marginal behaviour including polyphase retreat. Within this study, we examine the geomorphology, geology and internal structure of a terminal moraine complex - the 'Cromer Ridge' in north Norfolk to reconstruct patterns of ice-marginal behaviour. Previously, this landform was interpreted as the limit of a southern extension of the British Ice Sheet during a Middle Pleistocene glaciation. Evidence presented here reveals a more complicated pattern of ice-marginal behaviour with the 'Cromer Ridge' reinterpreted as a 'complex' comprising several ridge elements. We propose that the maximum ice extent lay further to the south, with the size and morphology of the largest ridge element (the 'Cromer Ridge' as previously defined) a facet of thrust-stacking at an ice-marginal stillstand. We recognise multiple oscillations of the ice-front recorded against a twelve-stage model for the decay of the southern margins of a fast-flowing lobe of North Sea ice. Changes in ice-marginal dynamics are identified by the superimposition and lateral and vertical evolution of glacitectonic styles. Differences between these various states, and switches between 'shallow' and 'deep' thinskinned glacitectonics, are strongly influenced by sub-marginal and proglacial water availability. Examination of the evidence for the morphostratigraphic proposals for the glacitectonic assemblage, within the context of the above interpretation, suggests that many of the 'glacigenic landforms' are erosional and a MIS 12 age of formation is favored although several anomalies remain to be explained.
\end{abstract}

\section{Introduction}

Terminal moraines are an important landform within the glacial landsystem and are widely recognised within both contemporary (Boulton et al., 1996, 1999; Bennett, 2001; Evans and Twigg, 2002; Evans, 2005; Benediktsson et al., 2010) and relict glacial environments (van der Meer, 1987; 
Lee, J.R., Phillips, E., Booth, S.J., Rose, J., Jordan, H.M., Pawley, S.M., Warren, M., Lawley, R.S. 2013. A polyphase glacitectonic model for ice-marginal retreat and terminal moraine development: the Middle Pleistocene British Ice Sheet, northern Norfolk, UK. Proceedings of the Geologists' Association, 124, 753-777. PRE-PROOF ACCEPTEF MANUSCRIPT.

Hart, 1990; Van der Wateren, 1995; Harris et al., 1997; Phillips et al., 2002; Wilson, 2002; Thomas and Chiverrell, 2007; Johnson et al., 2013). Previously, they have been considered as providing a visible record of a maximum extent of glacier advance, although many now consider them to provide a more dynamic record of glacier retreat (e.g. Thomas, 1984; Thomas et al., 2004; Thomas and Chiverrell, 2007; Lüthgens and Böse, 2011; Clark et al., 2012).

The formation of terminal moraines typically involves the complex interplay between ice-marginal to sub-marginal sedimentation and glacitectonics; the latter including proglacial and sub-marginal bulldozing, thrusting and squeezing (Benn and Evans, 2010) as a result of either 'thin-skinned glacitectonics' (Croot, 1987; Banham, 1988b) or 'gravity spreading' as a consequence of loading of the underlying sediment pile (Rotnicki, 1976; Van der Wateren, 1985; Aber et al., 1989). The morphology and internal structural architecture of terminal moraines, in particular the superimposition of different subglacial, sub-marginal and proglacial features, can provide detailed insights into larger-scale patterns of ice dynamics such as phases of ice advance, still-stand and retreat (Krüger, 1993; Van der Wateren, 1995, 2005; Thomas and Chiverrell, 2007). At a smaller scale, they can provide specific information regarding the mechanics of ice-marginal events, submarginal conditions and the ice-bed interaction. Several recent studies have suggested that terminal moraines may record evidence of surging glacier flow (Matthews et al., 1995; Krüger, 1996; Boulton et al., 1999; Bennett, 2001; Evans and Hiemstra, 2005; Benediktsson et al., 2009, 2010), or alternatively, substrate conditions leading to the termination of fast flow conditions (Christoffersen and Tulaczyk, 2003). Consequently, terminal moraines can provide valuable insights into the dynamics and nature of the ice-marginal landsystem, and potentially the internal and external controls that influenced glacier/ice sheet behaviour (Bennett, 2001; Benn and Evans, 2010).

A continually growing body of research has focused on relict terminal moraines in the UK, although much of this research is centered upon the dynamics and collapse of the Late Devensian British Ice Sheet (e.g. Thomas and Chiverrell, 2007; Evans and Thomson, 2010; Finlayson et al., 2010), and smaller terminal moraines relating to Younger Dryas ice (Phillips et al., 2002; Wilson, 2002; Benn and Lukas, 2006; Lukas and Benn, 2006). In this paper we focus on the genesis and significance of a much older terminal moraine complex in northeast Norfolk (eastern England), the 'Cromer Ridge'. Development of this terminal moraine has been widely attributed to the late Middle Pleistocene Anglian Glaciation, marking the limit of a late-stage advance of British Ice Sheet (BIS) flowing southwards down the North Sea (Boulton et al., 1984; Hart, 1990). However, others have associated its formation with glacitectonism occurring at the limit of a MIS 6 ('Saalian' stage) ice advance (Hamblin et al., 2005; Rose, 2009). Structural, sedimentological and geomorphological evidence presented here favour processes operating during the earlier glaciation, and have allowed the identification of three broad areas or "domains" associated with this relict moraine complex which record several phases of ice re-advance and still-stand as the Anglian BIS progressively retreated northwards.

\section{Geological and Geographical Background}

The study area is located in northeast Norfolk, eastern England, and lies adjacent to the western margins of the Southern North Sea Basin (Figure 1a,b). The region is situated beyond the maximum limit of the Late Devensian (Weichselian) glaciation (Pawley et al., 2006), but was repeatedly inundated by ice from the west (Central England) and north (North Sea) during the Middle Pleistocene (Perrin et al., 1979; Bowen et al., 1986; Hart and Boulton, 1991a; Lunkka, 1994; Clark et al., 2004; Scheib et al., 2011). Whether successive ice advances occurred during a single Anglian Glaciation (c.480-430ka) or multiple Middle Pleistocene glaciations centered on the Anglian is the 
Lee, J.R., Phillips, E., Booth, S.J., Rose, J., Jordan, H.M., Pawley, S.M., Warren, M., Lawley, R.S. 2013. A polyphase glacitectonic model for ice-marginal retreat and terminal moraine development: the Middle Pleistocene British Ice Sheet, northern Norfolk, UK. Proceedings of the Geologists' Association, 124, 753-777. PRE-PROOF ACCEPTEF MANUSCRIPT.

subject of ongoing debate (Boulton et al., 1984; Hamblin et al., 2000; Banham et al., 2001; Hamblin et al., 2005; Preece et al., 2009; Rose, 2009; Lee et al., 2011c, 2012).

The geology of the region consists of a thick layer of superficial deposits unconformably overlying bedrock; the latter comprising marl and fossiliferous limestone of the Cretaceous age Chalk Group (Mortimore et al., 2001, 2011; Moorlock et al., 2002). Bedding within the bedrock strikes northsouth and dips gently $\left(<1^{\circ}\right)$ to the east (Mortimore et al., 2001), with the regional rockhead surface, lying at a depth of between 15-20 m OD in the west of the study area, declining eastwards to beneath sea-level in the east (Figure. 1c). This rockhead surface is not flat, but contains a number of distinctive bedrock highs (e.g. Upper Sheringham, Trimingham, East Runton) and lows (e.g. Weybourne, Bessingham and Southrepps).

The Chalk Group is overlain by Early and early Middle Pleistocene age shallow marine and coastal silts, sands and sands and gravels (Wroxham Crag Formation), that contain lenses of organic alluvial muds (Cromer Forest-bed Formation) (Reid, 1882; West, 1980; Briant et al., 1999; Preece and Parfitt, 2000; Rose et al., 2001, 2002; Lee, 2009; Larkin et al., 2011). These pre-glacial sediments are in turn overlain by a thick glacigenic sequence comprising diamictons, glacilacustrine sands and muds, and glacifluvial outwash deposits. The stratigraphy of this sequence is now well-established with deposits linked into a succession of advances of the British Ice Sheet across north Norfolk (Reid, 1882; Banham, 1968; Hart and Boulton, 1991a; Lunkka, 1994; Lee et al., 2004; Pawley, 2006). The repeated advances of ice across the area has left a complex glacitectonic overprint on the preexisting sediment pile, informally referred to as the 'Contorted Drift' (Reid, 1882; Slater, 1926; Dhonau and Dhonau, 1963; Banham, 1975), with deformation having occurred in proglacial, submarginal and subglacial settings (Banham, 1966, 1975, 1977a; Hart, 1990; Hart and Boulton, 1991b; Fish et al., 2000; Roberts and Hart, 2005; Hart, 2007; Lee and Phillips, 2008; Phillips et al., 2008; Burke et al., 2009; Vaughan-Hirsch et al., 2013; Fleming et al., this volume; Phillips and Lee, this volume). A detailed tectonostratigraphy erected for the north Norfolk area has revealed a succession of structural events which have been correlated with repeated ice advances across the region (Banham, 1988a; Phillips et al., 2008; Lee et al., 2011a). Currently, a total of six major ice advances (A1-A6) have been recognised (Lee et al., 2011a) (Table 1). The first four events (A1-A4) correspond to the deposition of the Happisburgh, Corton, Walcott and Bacton Green Till members and record advances by British North Sea ice from the north (Lee et al., 2002, 2004). Each till is separated by variable thicknesses of glacilacustrine silts, clays and sands including the Mundesley Sand Member which crop-out between the Walcott and Bacton Green Till members. The sediment pile was then overridden and disrupted by ice advancing from the west/southwest (A5) leading to the formation of a glacitectonic mélange (Banham, 1965; Banham and Ranson, 1965; Lee and Phillips, 2008; Phillips et al., 2008; Fleming et al., this volume; Phillips and Lee, this volume), and the local deposition of a chalk-rich diamicton (Perrin et al., 1979; Ehlers et al., 1987; Ehlers et al., 1991; Pawley, 2006; Scheib et al., 2011). Recent work by Waller et al. (2009) and Waller et al. (2011) has suggested that an extensive permafrost developed prior to/during A5, with overriding of this 'warm permafrost' having influenced conditions within the bed of the ice sheet and the style of subglacial deformation. The final major ice advance (A6) marks a further incursion of ice from the north. The southern limit of this advance was marked by the development of a large composite moraine topped by outwash sands and gravels that forms the area of elevated ground between Trimingham and Fakenham known locally as the 'Cromer Ridge' (Boulton et al., 1984; Hart, 1990; Pawley et al., 2005) together with a range of more localised northerly-developed glacitectonic structures (Ehlers et al., 1987). The outwash, collectively known as the Briton's Lane Formation (dated by OSL to Marine Isotope Stage (MIS) 12 (Anglian) by Pawley et al., 2008), extends southwards from the 'Cromer Ridge' as a highly-degraded sheet that drapes over the pre-existing glacial deposits and topography (Straw, 1973; Moorlock et al., 2002). To the north of the 'Cromer Ridge', further sands and gravels 
Lee, J.R., Phillips, E., Booth, S.J., Rose, J., Jordan, H.M., Pawley, S.M., Warren, M., Lawley, R.S. 2013. A polyphase glacitectonic model for ice-marginal retreat and terminal moraine development: the Middle Pleistocene British Ice Sheet, northern Norfolk, UK. Proceedings of the Geologists' Association, 124, 753-777. PRE-PROOF ACCEPTEF MANUSCRIPT.

assigned to the Briton's Lane Formation have been recognised at lower elevations (Moorlock et al., 2002; Hamblin et al., 2005; Pawley, 2006) where they form a series of ice-contact landforms within the Glaven Valley (Sparks and West, 1964; Straw, 1973; Gray, 1997; Gale and Hoare, 2007).

Although unconstrained by geochronology or lithostratigaphy, it is widely assumed that these lower units were deposited as ice retreated northwards from the 'Cromer Ridge'. The retention of landform shapes characteristic of ice-contact topography (e.g. kames, kame terraces, outwash fans), has caused some (Hamblin et al., 2005; Rose, 2009) to propose by analogy with similar features in northern Europe, that these landforms were formed during the MIS 6 glaciation (Saalian of the Netherlands) although there is no independent geochronology to support this age attribution.

\section{Methodology}

Examination of the internal structure of terminal moraines has historically been achieved using direct observations of structure and sedimentology (Van der Wateren, 1995; Phillips et al., 2002; Benediktsson et al., 2009) and non-invasive geophysical methods such as GPR (Bakker, 2004; Kuriger et al., 2005). In this study, we employ a range of different field and remote techniques. Full sedimentological and lithological descriptions of each study site are beyond the scope of this 'structural' paper, and instead, readers are directed to relevant literature sources indicated within the text. For each site, the structural geology is described relative to the regional lithostratigraphy (Lee et al., 2004; Hamblin et al., 2005; Pawley, 2006) and published 1:50,000 scale geological maps of the Cromer (Sheet 131) and Aylsham (Sheet 147) districts (British Geological Survey, 2002, 2013). Correlating the geology of intensely glacitectonised sites with the regional lithostratigraphy, is however problematic, because many units are not within their primary stratigraphic position. To overcome this, general facies descriptions were supported with quantitative lithological analyses (e.g. particle size, heavy mineralogy, clast lithological analysis, calcium carbonate determination) to aid stratigraphic correlation. The structural (glacitectonic) features at each site examined during the present study were described following standard practices. The orientation of folds, foliations, faults, and lineations, as well as bedding were recorded from a number of points along the length of the section. The sense of asymmetry of various fold phases and movement on the faults, and interrelationships between the various generations of structures were established. Successive generations of folds (F1, F2 ....Fn), fabrics (S1, S2 ....Sn) and lineations ( $L 1, \mathrm{~L} 2 \ldots . . \mathrm{Ln})$ are distinguished by the nomenclature normally used in structural geological studies (S1 earliest fabric to Sn latest). However, this nomenclature does not necessarily imply that these structures were developed in response to separate deformation events (D1, D2.....Dn). Geomorphological data has been gathered from a 1:10,000 field survey, combined with data gathered from aerial photographs and a $3 \mathrm{~m}$ resolution Digital Surface Model with 'lines' digitised (1:5,000 scale) directly into a GIS shapefile.

\section{Description of Structural and Geomorphological Domains}

For ease of description the study area is sub-divided into three, approximately east-west-trending, geomorphological domains (see below), with Domain 1 being the most southerly, and Domain 3 occurring discontinuously along the northern part of the area adjacent to the North Sea coast (Figure 2). A fourth 'sandur' domain, not examined within this paper, extends southwards from Domain 1 towards Norwich.

\subsection{Domain 1 - Low relief morainic ridges}


Lee, J.R., Phillips, E., Booth, S.J., Rose, J., Jordan, H.M., Pawley, S.M., Warren, M., Lawley, R.S. 2013. A polyphase glacitectonic model for ice-marginal retreat and terminal moraine development: the Middle Pleistocene British Ice Sheet, northern Norfolk, UK. Proceedings of the Geologists' Association, 124, 753-777. PRE-PROOF ACCEPTEF MANUSCRIPT.

\subsubsection{Geomorphology}

Domain 1 forms a $7 \mathrm{~km}$ wide and $26 \mathrm{~km}$ long, wedge-shaped area between Hindolveston and Gimingham (Figure. 1c) comprising a series of low-amplitude, straight, crenulate or lobate ridges (1.5-5 $\mathrm{m}$ high, 30-80 $\mathrm{m}$ long) (Figure 2 ). In cross-section, the ridges vary between crudely symmetrical, gently sloping forms to asymmetrical features that possess slightly steeper northern flanks. The distance between ridge crests varies between 250 and $600 \mathrm{~m}$, although shorter and longer wavelengths do occur. However, it should also be noted that the expression of these relatively subtle landforms may have been modified by hill-wash and modern agricultural practices. Dissecting the ridges are several northwest to southeast-trending miss-fit valleys which extend northwards, upslope, into the southern margin of Domain 2. A number of the valleys occur parallel to the northern margin of the larger ridges, prior to turning southwards to cross-cut the landform. Although typically miss-fit, these valleys locally form the tributaries to the main modern drainage systems of the area - principally the Wensum, Bure and Ant rivers and Mundesley Beck.

\subsubsection{Geology}

Geological mapping at 1:10,000 scale carried out by the British Geological Survey $(2002,2013)$ has revealed that the geology of Domain 1 is both highly complex and spatially variable. Seven major lithofacies have been identified within the ridges and inter-ridge areas (Table 2). Augering reveals that individual ridges are composed of highly consolidated masses of stiff brown sandy diamicton (Lithofacies 1 / Bacton Green Till) either containing thin discontinuous to chaotic, inclusions of chalky diamicton (Lithofacies 2 / Weybourne Town Till) and/or sorted sediments (Lithofacies 3-6), or stacked with more coherent, repeated, slab-like units ( 0.3 and $1.2 \mathrm{~m}$ thick) of these lithofacies. The morphology and broad composition of the ridges is consistent with their interpretation as small moraine ridges (Benn and Evans, 2010).

The areas between the proposed moraines are mainly underlain by a coherent stratigraphy of Bacton Green Till (Lithofacies 1) locally overlain by Weybourne Town Till (Lithofacies 2). Less common, are beds of sorted sediment including massive clay (Lithofacies 3), rhythmically-bedded silt and clay (Lithofacies 4), poorly-sorted silty sand (Lithofacies 5 ) and heterogeneous admixtures of diamicton, sand, silt and clay (Lithofacies 6). The geometric relationship between the sorted sediments is largely chaotic, but in some areas a distinctive north to south gradation from relatively poorly-sorted lithofacies (e.g. Lithofacies 5 and 6) to more sorted facies (Lithofacies 3 and 4) was observed. The sedimentology and crude geometry of these deposits is suggestive of low-energy waterlain deposition, most probably within a series of localised glacilacustrine basins that formed between some of the moraine ridges. In these basins, low energy background sedimentation (Lithofacies 3 and the clay laminae of Lithofacies 4 ) was frequently punctuated by influxes of poorlysorted sediment that was either dumped rapidly (Lithofacies 5 ) or settled more slowly through the water column (silt laminae of Lithofacies 4). The diamictons that characterise Lithofacies 6 are interpreted as mass-flows, formed as slurries of water-saturated diamicton sloughing off the sides of the moraine ridges into the intervening basins.

\subsection{Domain 2 - Main topographic feature, the "Cromer Ridge"}

\subsubsection{Geomorphology}

Domain 2 corresponds to the main topographic feature within the region, the 'Cromer Ridge'. It comprises a main ridge that extends westwards from Trimingham and Overstrand on the northeast Norfolk coast, to West Beckham, before extending south-westwards to Melton Constable and thence northwestwards through Thursford and beyond (Figure 2a). The ridge is broadly 
Lee, J.R., Phillips, E., Booth, S.J., Rose, J., Jordan, H.M., Pawley, S.M., Warren, M., Lawley, R.S. 2013. A polyphase glacitectonic model for ice-marginal retreat and terminal moraine development: the Middle Pleistocene British Ice Sheet, northern Norfolk, UK. Proceedings of the Geologists' Association, 124, 753-777. PRE-PROOF ACCEPTEF MANUSCRIPT.

asymmetrical in form, possessing a gentle $\left(<1^{\circ}\right)$, south-facing slope that grades southwards into Domain 1. The slope, however, is not smooth but heavily degraded by post-glacial fluvial incision and slope processes. The north-facing slope of the ridge is steeper $\left(>3^{\circ}\right)$, possessing a gully and spur morphology with small dormant fans filling many of the gullies proximal to the main ridge, extending northwards towards the coast within a series of dry or miss-fit channels. These features indicate degradation and modification of the scarp by processes that locally yielded high sediment volumes and flashy high peak discharges. A possible mechanism would be freeze-thaw with nival-type flow regimes. Two distinct morphological zones may be recognised in Domain 2. Firstly, within the western part of the domain, are a series of low-amplitude ridges similar to those encountered within Domain 1. Their crests often form distinctive crop-marks which can be seen in aerial photographs. Typically, they are 1-3m height, and are aligned west-southwest to east-northeast in the south, but curve in an arc to their northern end in the vicinity of West Beckham where they are orientated south-southwest to north-northeast (Figure 2b). In the north and east of the domain they are truncated by a second set of low-amplitude, asymmetrical ridges aligned broadly west-east becoming west-southwest to east-northeast in the vicinity of Trimingham and Overstrand (Figure $2 b)$.

\subsubsection{Surface Geology}

The surface geology of Domain 2 is dominated by extensive spreads of coarse sand and gravel (Lithofacies 7) that range in thickness between 2-40 metres. Sands and gravels also extend southwards discontinuously across Domain 1 and beyond the southern limit of the current study area towards Norwich. Here, they occur as extensive bodies ( $<4 \mathrm{~m}$ thick), or more commonly, as thin veneers $(<0.7 \mathrm{~m})$ that partly drape the underlying topography. The deposits form part of the Briton's Lane Formation and record the development of a series of proglacial outwash sandurs (Cox and Nickless, 1972; Straw, 1973; Moorlock et al., 2002; Pawley et al., 2005). Their geometric relationship to the geology and landforms indicate that deposition post-dates the generation of Domain 1 and are probably contemporaneous with the formation of Domain 2.

\subsubsection{Gimingham Quarry}

Gimingham Quarry (National Grid Reference: TG 282 384) lies on the outskirts of Trimingham, approximately $600 \mathrm{~m}$ southeast of the southern end of the Trimingham-Overstrand coastal section (Section 4.2.4). Exposed sections within the quarry show three distinctive structural zones differentiated by the style and relative intensity of deformation (Figure 3a). Structural Zone G1 (SZG1) can be observed within the eastern quarry face between 45-50m OD. It exhibits a layer-cake sequence comprising beds of brown sandy diamicton (Bacton Green Till), overlain by a $2 \mathrm{~m}$ thick stratified sand, a higher chalk-rich diamicton (Weybourne Town Till), with a thin capping of stratified sand. The sequence is deformed by gentle, upright to sub-vertical open folds (F1) that form a series of north-northwest to south-southeast-trending synclines and anticlines with wavelengths ranging between $25-40 \mathrm{~m}$ and amplitudes of upto $3 \mathrm{~m}$.

Structural Zone G2 (SZ-G2) occurs within the northern quarry face between approximately 47-58m OD. It is composed of folded sandy diamicton (Bacton Green Till), which forms the core of a prominent antiform, and weakly cemented (carbonate) flint-rich sands and gravels (Briton's Lane Formation) that contain distinctive involuted 'drop-soil' periglacial structures (Figure 3b). These sediments are folded by a closed-to-tight, asymmetrical, SSE-verging anticline (F2) which occurs in 
Lee, J.R., Phillips, E., Booth, S.J., Rose, J., Jordan, H.M., Pawley, S.M., Warren, M., Lawley, R.S. 2013. A polyphase glacitectonic model for ice-marginal retreat and terminal moraine development: the Middle Pleistocene British Ice Sheet, northern Norfolk, UK. Proceedings of the Geologists' Association, 124, 753-777. PRE-PROOF ACCEPTEF MANUSCRIPT.

the hanging-wall of a southerly directed, sub-horizontal to gently northerly $\left(8^{\circ}\right.$ towards $\left.003^{\circ}\right)$ dipping thrust (T1) which forms the glacitectonic boundary between zones SZ-G1 and SZ-G2. The axial plane of the $F 2$ anticline is steeply-inclined $\left(64-77^{\circ}\right)$, striking broadly west-northwest to east-southeast $\left(267-276^{\circ}\right)$. Bedding and open F1 folds within structurally underlying SZ-G1 are clearly truncated by the detachment at the base of SZ-G2 (Figure 3a), and, therefore, deformation within SZ-G1 predated thrusting. In contrast, folding within SZ-G2 probably accompanied thrusting in response to shortening within the hanging-wall of this detachment (i.e. a fault propagation fold).

Structural Zone G3 (SZ-G3) is the highest structural zone within Gimingham Quarry and consists of undeformed horizontally-bedded and cross-bedded, flint-rich sands and gravels that are lithologically identical to those within SZ-G2. These higher-level sands and gravels, also part of the Briton's Lane Formation, contain 'drop-soil' structures and occasional intra-formational frost cracks. The boundary between SZ-G3 and the underlying zone SZ-G2 is undulatory and erosional, indicating that $\mathrm{F} 2$ folding and thrusting was accompanied or followed by a period of erosion prior to the continued deposition of the Briton's Lane Formation.

\subsubsection{Trimingham to Overstrand coastal section}

The Trimingham (TG 280,390) to Overstrand (TG 240,145) coastal section provides a southeast to northwest oblique section through the main ridge forming Domain 2. The geology has been variably described by a number of workers (Banham, 1968, 1970; Banham et al., 1975; Hart, 1990, 1992; Lunkka, 1994; Burke et al., 2009; Lee et al., 2011b; Vaughan-Hirsch et al., 2011), but the stratigraphy and glacitectonic evolution of the exposed sequence has remained equivocal (Roberts and Hart, 2000) due to the highly complex, poly-deformed nature of the sedimentary sequence and frequent obscuring of the section by large landslides (Lee et al., 2011b). Within this present study, the coastal section is sub-divided into four separate structural zones (Figure 4). Deformation from the preceding A5 event (Table 1 ) is also evident discontinuously along the section, for example between 2000-2300m, but is not described here.

Structural Zone T1 (SZ-Tr1) occurs at the southeastern (Trimingham) end of the coastal section between 100-825 $\mathrm{m}$ where the glacial and pre-glacial sequence is deformed by a series of thrust faults that link into a major basal décollement or sole thrust. The basal décollement (T1) is developed within the lower part of the sediment pile and climbs southwards through the Happisburgh Till, into the overlying rhythmically-bedded glacilacustrine deposits and Walcott Till along tectonic 'ramps' and 'flats'. The sub-horizontal 'flats' typically occur beneath the thicker, relatively competent clay beds present within the rhythmically-bedded glacilacustrine deposits indicating a lithological control on thrust propagation. At the southern end of the zone, the thrusts climb rapidly to form an imbricate thrust stack or fan composed of moderately to steeply-inclined listric reverse faults (T2-T5 on Figure 4). These faults resulted in the stacking of detached blocks of Happisburgh Till and the younger (post Walcott Till) rhythmically-bedded glacilacustrine deposits (see between $180-420 \mathrm{~m}$ on Figure 4). The individual thrust-bound slice young towards the northwest. However, the relative age of the sediments within this imbricate fan increases northwards recording the progressive emplacement/over-thrusting of relatively older parts of the sequence at a higher structural level into the developing thrust stack. Two sets of cross-cutting slickensides have been identified on the exposed surfaces of the anastomosing $T 2$ thrust, recording a polyphase history of movement on this fault including an earlier N-S phase of movement, followed by a relatively younger NW-SE displacement. Towards the southern end of the zone (at c. $125 \mathrm{~m}$, Figure 4) the structurally lower T1 fault was observed truncating the Briton's Lane Formation sands and gravels, indicating that thrusting continued during the deposition of at least the lower parts of 
Lee, J.R., Phillips, E., Booth, S.J., Rose, J., Jordan, H.M., Pawley, S.M., Warren, M., Lawley, R.S. 2013. A polyphase glacitectonic model for ice-marginal retreat and terminal moraine development: the Middle Pleistocene British Ice Sheet, northern Norfolk, UK. Proceedings of the Geologists' Association, 124, 753-777. PRE-PROOF ACCEPTEF MANUSCRIPT.

this outwash sequence. The fault T5 denotes the upper boundary of this zone of brittle thrusting, forming the boundary between zones SZ-Tr1 and the structurally overlying SZ-Tr2.

In contrast to the thrusting of zone SZ-Tr1, structural Zone 2 (SZ-Tr2) (270-2650m, Figure 4) is characterised by large-scale folding which accommodated approximately $16.8 \%$ shortening of the glacigenic sequence within the hanging-wall of a major detachment (thrust) located below the section. The folds are symmetrical to slightly asymmetrical, concentric, open synclines and anticlines (Figure 5a) which affect the entire sequence exposed in this area, including the overlying Briton's Lane Formation. At the northwestern end of the zone (between 1750-2650m Figure 4) the mesoscale, relatively open folds (with wavelengths between $20-80 \mathrm{~m}$ and amplitudes $<10 \mathrm{~m}$ ) are better developed within the structurally lower parts of the sequence, upto and including the Bacton Green Till. Further south, beyond $1750 \mathrm{~m}$, the scale (with wavelength $250-500 \mathrm{~m}$ ) and amplitude $(10-35 \mathrm{~m}$ ) of the folds increases dramatically (Figure 4). The upright to moderately-inclined, WNW-ESEtrending anticlines and intervening synclines plunge towards the south to southwest or north to northeast. The fine-grained, rhythmically-bedded glacilacustrine deposits locally exhibit a distinctive chevron-style of folding (with wavelengths between 0.3-0.5m and amplitudes of 0.2-0.4m); for example at $1170 \mathrm{~m}, 1280 \mathrm{~m}$ and $1500 \mathrm{~m}$ (Figure 4; Figure 5b). Between $1170-1500 \mathrm{~m}$ (Figure 4) the Briton's Lane Formation occurs within the core of a large open syncline with bedding-surfaces (horizontal to sub-vertical inclined) broadly aligned parallel to the margins of the fold. It indicates that folding continued or may even have post-dated the deposition of at least the older parts of this sand and gravel outwash sequence, and clearly demonstrate the association of this deposit with the glacitectonic event.

Structural Zone 3 (SZ-Tr3) occurs to the southeast of Overstrand (between 2500-3000 m, Figure 4) and is dominated by two large $(10-15 \mathrm{~m}$ thick, $10-50 \mathrm{~m}$ long) glacitectonic rafts composed of bedded chalk capped by pre-glacial sands and gravel of the Wroxham Crag Formation (Burke et al., 2009; Vaughan-Hirsch et al., 2011). The upper of these rafts is deformed by a large-scale, asymmetrical anticline which verges towards the south (see Figures 4 and 6a). This monoclinal fold structure is developed within the hanging-wall of a gently to moderately $\left(25^{\circ}-35^{\circ}\right)$ northwest dipping brittle thrust which forms the main décollement surface at the base of the raft. Bedding within the Wroxham Crag Formation immediately below this décollement is deformed by a meso-scale, closed to tight, moderately-inclined syncline, small-scale thrusts (dip $30^{\circ}-40^{\circ}$ to north) and Riedel shears (offset of 1 to $2 \mathrm{~cm}$ ) which yield a sense of displacement towards the south (Vaughan-Hirsch et al., 2011). Kinematic indicators within this c. $1 \mathrm{~m}$ thick zone of deformation clearly indicate that the direction of thrusting responsible for the accretion of the rafts within SZ-Tr3 is the same as that resulting in the thrust repetition of the glacigenic sequence observed in zone SZ-Tr1.

Further to the northwest within Structural Zone 4 (SZ-Tr4) (between $2980 \mathrm{~m}$ and $4500 \mathrm{~m}$, Figure 4) the essentially layer-cake (?parautochthonous) sequence of Happisburgh Till, rhythmically-bedded glacilacustrine deposits, Walcott Till and pale grey micaceous and chalky sands (Mundesley Sands) in the structurally lower part of the section are deformed by a series of open, steeply-inclined to upright, meso-scale to large-scale synclines and anticlines (wavelengths between 30-50m, amplitudes up to $3 \mathrm{~m}$ ). Folding is thought to have occurred in response to shortening (estimated amount of shortening accommodated by folds c. 5\%) within the hanging-wall of an inferred thrust located beneath the level of the foreshore. However, in the upper part of zone SZ-Tr4 (above $20 \mathrm{~m}$ O.D.), the allochthonous sedimentary sequence has been dissected by a number of north-westerly dipping gently $\left(8^{\circ}-21^{\circ}\right)$ inclined thrusts. The sediments within the individual thrust-bound slices, or nappes, are deformed by a series of large-scale (wavelengths $30-50 \mathrm{~m}$ ), moderately-inclined, tight to isoclinal, asymmetrical folds which verge towards the south or southeast (Figure 4; Figure 6b). Bedding within the cores of these folds is locally off-set by a number of low-angle, northerly dipping 
Lee, J.R., Phillips, E., Booth, S.J., Rose, J., Jordan, H.M., Pawley, S.M., Warren, M., Lawley, R.S. 2013. A polyphase glacitectonic model for ice-marginal retreat and terminal moraine development: the Middle Pleistocene British Ice Sheet, northern Norfolk, UK. Proceedings of the Geologists' Association, 124, 753-777. PRE-PROOF ACCEPTEF MANUSCRIPT.

thrusts (e.g. at $3300 \mathrm{~m}$; Figure $6 \mathrm{~b}$ ). These small-scale thrusts (throw of $1-3 \mathrm{~m}$ ) occur parallel to the axial planes of the folds and probably developed as these ductile structures continued to tighten in response to further shortening of the sedimentary pile. Extending northwards from $4250 \mathrm{~m}$ to the end of the section $(4500 \mathrm{~m})$ similar fold and thrust structures are evident; however, these are variably over-printed by later soft-sediment deformation. At $4250 \mathrm{~m}$, for example, the Bacton Green Till has been folded around a core of sand forming an asymmetrical, broadly recumbent, over-turned antiform (Figure 7). Fold vergence is towards the southeast coincident with the up-dip direction of the axial plane of the fold. Water-escape structures and flame-like to diapiric contacts between and within the folded beds are common indicating that these sediments possessed relatively high porewater contents at the time of deformation. At the southeastern end of the section, the fold is truncated by a vertical flame-like diapir of Bacton Green Till with internal tectonic layering coplanar to the diapir margins. The northwest margin of the diapir is bounded by a $0.5 \mathrm{~m}$ wide vertical to subvertical sand-filled fracture. Bedding within the fracture is aligned parallel to the fracture margins.

The boundary between the two structurally contrasting subzones identified within zone SZ-Tr4 is formed by a prominent, sub-horizontal to gently $\left(\right.$ c. $\left.5^{\circ}-12^{\circ}\right)$ northerly dipping brittle thrust which is largely located within the Mundesley Sands (Figure 4). Bedding within the micaceous sands immediately adjacent to this thrust (to a depth of c. $0.8 \mathrm{~m}$ ) has locally been transposed/overprinted by a pervasively developed glacitectonic foliation which occurs coplanar to this brittle fault. Between $3200-3350 \mathrm{~m}$, an imbricate stack of five, relatively small chalk bedrock rafts occurs within the hanging-wall of the thrust (see Figure 4). The individual rafts dip gently out of the cliff face (i.e. towards the north), however, their orientation has probably been modified due to present day gravitational slip as the cliff-line has receded.

\subsubsection{West Runton, Roman Camp}

Roman Camp (TG 188,415), West Runton, is situated on the northern scarp slope of Domain 2, approximately $1.5 \mathrm{~km}$ south of the coast (Figure 2). At this locality small, discontinuous sections through the scarp slope occur within a series of deep gullies that extend northwards into Domain 3. The exposed sections comprise thin $(<0.9 \mathrm{~m})$, fault-bound wedges of Bacton Green Till and Weybourne Town Till that have been thrust upwards into lower part of the overlying Briton's Lane Formation. These low-angle $\left(10^{\circ}-23^{\circ}\right)$ thrusts dip towards the north and northwest, with the offset of bedding across these faults (throw 0.6-2.4 $\mathrm{m}$ ) recording a sense of displacement towards the south/southeast. The sands and gravels at a higher structural/stratigraphic level within the Briton's Lane Formation at this site are unaffected by thrusting, indicating that these sediments were either deposited during or after deformation, or that thrusting had ceased before these brittle structures had propagated upwards through the entire sequence.

\subsection{Domain 3 - area between the 'Cromer Ridge' and the present coast}

\subsubsection{Geomorphology}

Domain 3 is situated between the base of the scarp of Domain 2, and the present coastline. It is characterised by a comparatively low-relief (20-35m OD), gently undulating area dissected by numerous dry and miss-fit valleys (Figure 2). Several of the larger valleys extend northwards linking the gullies that dissect the scarp slope of the 'Cromer Ridge' to the coastline. The distinctive topographic element of this domain is the occurrence of several steep-sided rounded hills (up to $30 \mathrm{~m}$ higher than the surrounding land-surface) that occur along the modern coastline at Beeston Hill (TG 166 433) and Skelding Hill on the eastern and western outskirts of Sheringham, and Lighthouse Hills, Cromer (TG 231,416). The exposed coastal sections through Beeston Hill were relatively poor 
Lee, J.R., Phillips, E., Booth, S.J., Rose, J., Jordan, H.M., Pawley, S.M., Warren, M., Lawley, R.S. 2013. A polyphase glacitectonic model for ice-marginal retreat and terminal moraine development: the Middle Pleistocene British Ice Sheet, northern Norfolk, UK. Proceedings of the Geologists' Association, 124, 753-777. PRE-PROOF ACCEPTEF MANUSCRIPT.

exposed during the present study and consequently, no new information was obtained regarding the internal structure or sediment architecture of this feature was obtained. However, detailed sections published by Dhonau and Dhonau (1963) demonstrate a structure and form largely similar to that within Skelding Hill.

\subsubsection{Weybourne Town Pit, Weybourne}

Weybourne Town Pit (TG 114,430) is a small disused quarry situated $600 \mathrm{~m}$ south of the coast at Weybourne. Previous workers (Baden-Powell, 1948; Banham and Ranson, 1965; Fish et al., 2000; Hart, 2007) have concluded that the deformed sediments exposed within this quarry can be broadly equated with the glacitectonised sequence seen on the nearby coast. These coastal sections are dominated by a glacitectonic mélange produced by subglacial deformation (Pawley et al., 2004; Hart, 2007) associated with the easterly directed A5 event (Table 1) of Lee et al. (2011a). However, the style and kinematics of the predominantly brittle-state deformation recorded by the sequence at Weybourne Town Pit contrasts marked with the highly-ductile A5 deformation seen along the coast, leading to a more recent study (Evans et al., 2011) concluding that glacitectonism at this site is better equated with a later A6 event (Table 1 ).

Deformation at Weybourne Town Pit resulted in the stacking of alternating thrust-bound slices of Bacton Green and Weybourne Town till (see Lee, 2003; Evans et al., 2011; Figure 8). The thickness of the individual tectonic slices of diamicton are highly variable ranging from $<10 \mathrm{~cm}$ up to c. $1 \mathrm{~m}$ thick. However, the scale of this thrusting is relatively minor when compared with the magnitude of the glacitectonic deformation recorded elsewhere along the coast. The low-angle thrusts bounding the slices of Bacton Green and Weybourne Town till exposed within Weybourne Town Pit dip towards the north (i.e. into the quarry face) and form an anastomosing network of relatively closely spaced brittle structures which record an apparent sense of movement towards the south. Thin zones of a wispy banding or foliation are locally developed immediately adjacent to the thrusts. The Weybourne Town Till, although typically massive, locally preserves evidence of soft-sediment deformation (Figure 8) which possibly accompanied the formation of the diamicton. These ductile structures, which include small-scale, highly attenuated flame-like folds, are clearly truncated by the thrusts, indicating that thrusting and imbrication of the Bacton Green and Weybourne Town tills post-dated this earlier phase of soft-sediment deformation. Both the soft-sediment deformation structures and thrusts are offset by a set of small-scale (throw of 2-25 cm), high-angle normal faults (which downthrow to the west) (Figure 8).

\subsubsection{Skelding Hill, Sheringham}

Skelding Hill is a prominent, steep-sided hill situated immediately adjacent to the coast, one kilometer to the west of Sheringham (Figure. 2). The coastal section through the hill reveals that, at its eastern end, this landform comprises thrust-stacked slabs of Happisburgh Till, Walcott Till, Bacton Green Till and pre-glacial Wroxham Crag Formation (see Figure 2 of Phillips and Lee, 2013). The Bacton Green Till beneath Skelding Hill is represented by a poly-deformed mélange facies containing variably deformed sand intraclasts and small rafts or blocks of chalk within fine grained sandy matrix. The well-developed glacitectonic foliation or stratification present in the mélange matrix is deformed by a set of, easterly verging folds, thrust and shear zones formed during the A5 event (Table 1). These early structures and tectonised slices of glacial and pre-glacial sediments have locally been deformed by a number of later, asymmetrical southerly-verging folds with northeasterly dipping axial surfaces (Figure 9). These southerly directed folds locally result in the overturning of 
Lee, J.R., Phillips, E., Booth, S.J., Rose, J., Jordan, H.M., Pawley, S.M., Warren, M., Lawley, R.S. 2013. A polyphase glacitectonic model for ice-marginal retreat and terminal moraine development: the Middle Pleistocene British Ice Sheet, northern Norfolk, UK. Proceedings of the Geologists' Association, 124, 753-777. PRE-PROOF ACCEPTEF MANUSCRIPT.

bedding within the sands and gravels on the inverted steeply-inclined limbs of these meso-scale, non-cylindrical, structures. In the core of one of these folds, bedding within the Wroxham Crag Formation is deformed by a set of small-scale, east-west-trending parasitic folds (S, M and Z) and southerly-directed, moderate to gently northerly dipping thrusts and shears (Figure 9), with the relatively later thrusting accommodating the further tightening of the fold as deformation progressed.

In the central part of Skelding Hill (TG 14755 43534) a large, 30-40 m long and 20-25 m thick, raft of chalk has been emplaced into the imbricate thrust stack composed of Happisburgh Till, Bacton Green Till and Wroxham Crag Formation (Figure 10; also see Figure 2 of Phillips and Lee, 2013). A major décollement (thrust) separates this allochthonous, thrust-repeated sequence from the underlying autochthonous (in situ) sands and gravels of the Wroxham Crag which, further westwards along the coast, is seen to rest upon the chalk bedrock. Bedding and other primary sedimentary structures within the upper 10 to $20 \mathrm{~cm}$ of the Wroxham Crag are progressively overprinted, becoming transposed (replaced) by a closely spaced glacitectonic layering which is co-planar with the fabric developed within the overlying diamicton. The base of the chalk raft is formed by prominent thrust which, overall, dips towards the north/northwest. A well-develop striation/lineation observed on the exposed surfaces of this thrust records transport direction from north to south. Immediately below the base of the chalk, the Bacton Green Till is highly deformed and possesses a well-developed glacitectonic foliation which is coplanar with the base of the overlying raft, defining a $30-50 \mathrm{~cm}$ thick ductile shear zone. This foliation wraps around variably rounded clasts of chalk included within the till. The Bacton Green Till thins rapidly beneath the raft, with the Happisburgh Till being cut out against the décollement at the top of the underlying, in situ, Wroxham Crag Formation (Figure 10).

Internally, the chalk raft is deformed by several gentle to steeply northerly-dipping (i.e. out of the cliff face) thrusts which are marked by a locally well-developed and closely-spaced fracture cleavage. The sense of displacement along these thrusts is poorly-constrained, although a locally crudely developed S-C-like fabric (shear-crenulation) geometry defined by the fracture cleavage suggests a sense of movement towards the south. The slightly oblique section provided by the cliff face at the eastern end of the raft indicates that the individual thrusts ramp upwards towards the south/southeast (i.e. into the cliff face) (Figure 10). In this area, near the top of the cliff, the chalk thins rapidly and the variably preserved bedding and/or fracture cleavage are deformed by a complex assemblage of southerly-verging folds and convolute fold-structures. Comparable southerly-verging folds and thrusts have been recognised deforming the structurally underlying allochthonous block of Wroxham Crag Formation.

The dissected dome-like morphology of Skelding Hill, coupled with its intensely folded and thrusted internal structure, is akin to that of a thrust-block moraine (Benn and Evans, 2010). Two broad phases of glacitectonic deformation may be recognised. The first phase (A5) resulted in the thruststacking of diamicton and Wroxham Crag Formation sand and gravel seen at the eastern end of the landform. This has been overprinted by a second southerly-directed tectonic event that has folded the thrust-stacked beds and emplaced the chalk raft and underlying thrust-stacked diamicton/sand and gravel in the central part of Skelding Hill.

\subsubsection{Stody Pit, Holt}

The site located at Stody (TG 056 345) comprises a small gravel pit located in the Glaven valley, $3 \mathrm{~km}$ to the southwest of Holt (Figure 2). The site is situated on the northern slope of the 'Cromer Ridge' on the boundary between domains 2 and 3 , close to the meltwater outlet through the ridge near the 
Lee, J.R., Phillips, E., Booth, S.J., Rose, J., Jordan, H.M., Pawley, S.M., Warren, M., Lawley, R.S. 2013. A polyphase glacitectonic model for ice-marginal retreat and terminal moraine development: the Middle Pleistocene British Ice Sheet, northern Norfolk, UK. Proceedings of the Geologists' Association, 124, 753-777. PRE-PROOF ACCEPTEF MANUSCRIPT.

Briston Gap. The only previous published description of the site is given by Ehlers et al. (1987) who described former quarry sections as containing lenses of chalk-rich till, overlain by outwash deposits and sandy till, which were interpreted as flow tills.

Examination of a freshly exposed section during 2004 revealed that sands and gravels of the Briton's Lane Formation occur at the base of the exposed sequence. These have been glacitectonised beneath a tectonically-emplaced unit of Weybourne Town Till Member (Figure 11). Glacitectonic deformation of the gravels occurred when several fault-bounded slabs of cobble gravel were imbricately-stacked during the propagation of low angle thrust faults $\left(16-30^{\circ}\right)$ that dip towards the northwest (Figure 11). Following emplacement, the uppermost cobble gravel slab was subject to further deformation during ice overriding, with attenuation structures marking the development of a ductile shear zone within a unit of clayey sand and matrix-supported gravel, including boudinage and tails of gravel being sheared into the overlying Weybourne Town Till Member. The shear zone sediments are also cut by several small (cm-scale), sub-vertical matrix-supported gravel dykes that record hydro-fracturing of the sequence and dewatering as the deformation ceased. Deformation of the sequence likely occurred during the A6 event of Lee et al. (2011a), with both structural and lithological indicators in the Weybourne Town Till Member demonstrating a northern provenance (Pawley, 2006). The till at this locality has also been subject to advanced post-depositional decalcification resulting from the percolation of acid groundwater, with the exception of in strain hardened areas located close to the thrust planes.

\section{Discussion}

The evolution of the three geomorphological domains identified in North Norfolk can be described in terms of a complex ice-marginal model associated with the final (A6; Table 1) oscillation of the North Sea ice lobe of the Middle Pleistocene British Ice Sheet. In particular, the model can be used to demonstrate that rather than simply representing a static ice maximum (Boulton et al., 1984; Hart, 1990; Hamblin et al., 2005; Pawley, 2006; Lee et al., 2011a), the 'Cromer Ridge' forms one component within a more complex and extensive landsystem that records active ice-marginal retreat from a maximum extent located further to the south.

\subsection{Bed conditions during initial ice advance}

Structures and landforms within the three domains in north Norfolk reveal marked differences in the scale and style of moraine development, and in-turn, the level of interaction between the icemargin, its base, and the underlying substrate. As noted above, the style of glacitectonics throughout much of the landsystem conform to a 'thin-skinned' model (Croot, 1987; Banham, 1988b). Within Domain 3, the deforming zone is spatially restricted (i.e. 'shallow') with the glacial and pre-glacial sequence preserving deformation structures associated with the earlier A5 (Table 1) west to east ice advance. These sediments remained largely unaffected by the A6 (Table 1) advance despite the whole of the domain having been overridden by this ice. For example, comparatively few sites along the coastal section of Domain 3 between West Runton and Weybourne exhibit this late phase of southerly directed deformation (Dhonau and Dhonau, 1963; Banham and Ranson, 1965; Pawley et al., 2004; Phillips et al., 2008), likewise inland sections at Glandford Quarry (TG 053 415) only display tectonism relating to the $A 4$ and $A 5$ events (Pawley, 2008). Furthermore, much of the deformation within Domains 1 and 2 can be equated with the 'active retreat' of the A6 North Sea ice, rather than its initial advance. These observations imply that there was minimal, or only localised 'shallow' ice-substrate coupling during the initial advance of the A6 North Sea ice front 
Lee, J.R., Phillips, E., Booth, S.J., Rose, J., Jordan, H.M., Pawley, S.M., Warren, M., Lawley, R.S. 2013. A polyphase glacitectonic model for ice-marginal retreat and terminal moraine development: the Middle Pleistocene British Ice Sheet, northern Norfolk, UK. Proceedings of the Geologists' Association, 124, 753-777. PRE-PROOF ACCEPTEF MANUSCRIPT.

across North Norfolk. This advance phase resulted in the deposition of the pale grey, chalk-rich northern-derived facies of the Weybourne Town Till (interpreted as a subglacial traction till (cf.Evans et al., 2006)) and was accompanied by very little, if any, shear being transmitted into the underlying sedimentary sequence.

The simplest explanation is that the traction zone at the base of the A6 ice was effectively decoupled from the underlying cohesive bed (A5 deformation structure), either by a thin deformable bed, potentially represented by early soft sediment deformation within the Weybourne Town Till, or a veneer of pressurised water (Kjær et al., 2006; Fischer et al., 2011). Basal conditions, such as those inferred here, often accompany fast or surging ice flow behaviour (Ó Cofaigh and Evans, 2001; Lian et al., 2003). Generic recognition of surging behaviour is provided by a range of sedimentological and landform features, however, few features on their own are unequivocally diagnostic of this type of flow mechanism (Evans et al., 1999; Evans and Rea, 1999; Evans and Rea, 2005; Evans et al., 2008). Decoupling of the ice from its bed as a result of either the development of a deformable bed or basal sliding, possibly leading to fast or surging flow, would have facilitated the advance of the A6 North Sea Ice across North Norfolk to its interpreted limit at the southern margin of Domain 1. Deformation observed within Domains 1 and 2, and to a much lesser extent Domain 3 record the progressive active retreat of this $A 6$ ice from its maximum limit.

\subsection{Thin-skinned glacitectonism and moraine construction during active retreat}

\subsubsection{Domain 1 - proglacial to ice marginal sedimentation and thrusting}

The geomorphology and geology of Domain 1 comprising a series of low-relief moraine ridges, separated by expanses of glacilacustrine deposits overlying a subglacial diamicton (Weybourne Town Till), are consistent with its origin as part of a proglacial to ice-marginal landsystem (Evans et al., 1999; Evans, 2005). The small morainic ridges preserved within this domain are thought to record a progressive retreat of the ice from the maximum position (Stage 1, Figures 12, 13), at or beyond the southern edge of Domain 1, progressively northwards to its northern boundary (Stage 2). The successive (south to north) generation of these moraines may be interpreted as a combination of ice marginal/sub-marginal imbrication and tectonic stacking of the pre-existing sedimentary sequence (Evans et al., 1999; Evans and Twigg, 2002) and/or proglacial thrusting with the moraines representing landforms developed above the propagating tips of the developing thrust faults (c.f. Phillips et al., 2008). The occurrence of discontinuous bodies of glacilacustrine deposits between the moraine ridges demonstrate that meltwater and small lacustrine basins were an active component of the glacier foreland during this initial phase of retreat, something that is typical of many proglacial areas (Benn and Evans, 2010).

One important implication of this interpretation of the geomorphology and glacial geology of Domain 1 is that the 'Cromer Ridge' can no longer be considered to represent the maximum extent of the A6 North Sea Ice lobe, but formed as a result of a later phase of ice marginal glacitectonism during the active retreat of the British Ice Sheet (see below).

\subsubsection{Domain 2 - ice marginal to sub-marginal glacitectonism}

Domain 2 is dominated by the 'Cromer Ridge' (Boulton et al., 1984; Hart, 1990; Pawley et al., 2005) which is interpreted as a large composite push or thrust-block moraine (Hart, 1990; Benn and Evans, 2010). The geomorphology of the domain, plus coastal exposures between Trimingham and Overstrand, and inland sections at Gimingham Quarry and the Roman Camp, clearly demonstrate 
Lee, J.R., Phillips, E., Booth, S.J., Rose, J., Jordan, H.M., Pawley, S.M., Warren, M., Lawley, R.S. 2013. A polyphase glacitectonic model for ice-marginal retreat and terminal moraine development: the Middle Pleistocene British Ice Sheet, northern Norfolk, UK. Proceedings of the Geologists' Association, 124, 753-777. PRE-PROOF ACCEPTEF MANUSCRIPT.

that the 'ridge' contains many individual morphological elements and cannot simply be explained by a single-phase model. Low-amplitude ridges that extend across much of the western half of the domain are tentatively interpreted as moraine ridges and form a continuum with those across much of Domain 1. They record a pattern of progressive retreat of the ice margin towards the northwest. Similarly orientated moraine ridges to the south of Trimingham are also likely to form part of this continuum, with sections at Gimingham Quarry providing a view of the internal structure, of one of these moraine ridges. Deformation structures present within the quarry record a distinct polyphase deformation history comprising an early phase of relatively upright, open folding (characteristic of zone SZ-G1), followed by later southerly-directed thrusting, asymmetrical folding (zone SZ-G2) and tectonic thickening of the sequence associated with ice pushing from the north/northwest. The style and intensity of deformation at this locality is consistent with proglacial to ice-marginal tectonism described by Van der Wateren (1995). The later phase of folding and thrusting which characterises zone SZ-G2 at Gimingham Quarry also affects the lower part of the Briton's Lane Formation. However, the upper part of this outwash sequence is undeformed (zone SWZ-G3; Figure 3) implying a cessation of compressive stresses. These relationships are consistent with glacitectonism occurring in an ice-marginal setting, contemporaneous with the deposition of at least the lower part of the Briton's Lane Formation. This sequence of outwash sands and gravels mantle the 'Cromer Ridge', and were clearly being laid-down during the development of this thrust-moraine. Outwash drainage extended southwards depositing a now discontinuous veneer of deposits that drape the underlying topography. Uplift associated with the thrust-stacking and imbrication of the pre-existing sediments during the formation of this major landform clearly resulted in penecontemporaneous erosion and possible incision on its southern flanks, prior to continued ice-marginal sedimentation. Proglacial sedimentation is likely to have continued uninterrupted further away from the developing thrust-block moraine.

The area to the north of a line linking Trimingham and West Beckham corresponds to a marked change in structural and moraine-ridge orientation from west-southwest to east-southeast, to westeast. Deformation observed in the Trimingham-Overstrand coastal section (SZ-Tr1 to SZ-Tr4), to the north of Gimingham Quarry, is most simply interpreted in terms of a 'deeper' thin-skinned thrust model (Figures 4 and 7). The southern-most structural zone (Zone SZ-Tr1; Figure 4) is dominated by a northerly (hinterland) dipping imbricate fan or 'schuppen zone' which forms the near-surface expression of a major detachment or sole thrust which developed at the base of the glacitectonised sequence. The repeated stacking of thrust-bound slices of the pre-existing sediments by successive detachments (T1 to T5 on Figure 4) as the zone of active thrusting stepped progressively northwards led to the accretion of successively older parts of the sequence into the developing imbricate fan (Figure 4). Thrusting within zone SZ-Tr1 also affected the Briton's Lane Formation, providing further evidence for glacitectonism having coincided with the deposition of at least the stratigraphically older parts of this extensive outwash succession. The high-angle and geometry of the faulting in this zone are consistent with deformation having occurred in a proglacial to ice-marginal setting (Hart et al., 1990; Van der Wateren, 1995; Benediktsson et al., 2009). Krüger (1993) and Evans and Twigg (2002) have suggested that relatively large thrust-moraines composed of high-angle faulted blocks provide a record of ice-marginal still-stand. Work by Dahlen et al. (1984) and Nieuwland et al. (2000) has shown that the structural style and geometric characteristics of a developing thrust-complex is strongly controlled by the frictional properties of the sequence undergoing deformation. For example, high-frictional (dry) sediments promote the development of steeply-inclined thrusts and the detachment of relatively short slabs of sediment. It is possible, therefore, that the steeplyinclined imbricate fan present within zone SZ-Tr1 records the deformation of a relatively dryer more consolidated part of the glacial sequence during the initial stages of the development of the 'Cromer Ridge'. 
Lee, J.R., Phillips, E., Booth, S.J., Rose, J., Jordan, H.M., Pawley, S.M., Warren, M., Lawley, R.S. 2013. A polyphase glacitectonic model for ice-marginal retreat and terminal moraine development: the Middle Pleistocene British Ice Sheet, northern Norfolk, UK. Proceedings of the Geologists' Association, 124, 753-777. PRE-PROOF ACCEPTEF MANUSCRIPT.

In contrast to the thrust-dominated deformation in zone SZ-Tr1, SZ-Tr2 is characterised by open, upright folding (Figure 4) marking a major change in the style of deformation during the construction of the 'Cromer Ridge'. Folding occurred in response to continued shortening (estimated 16.8\%) within the hanging-wall of a proposed basal décollement located at the base of the glacitectonised sequence. The open style of folding within this zone is consistent with a proglacial rather than icemarginal setting (Van der Wateren, 1995), indicating that the North Sea ice front had retreated further to the north. The southern section of the basal décollement is stratigraphically constrained, either within the glacilacustrine clays and silts, or at the boundary between these fine-grained deposits and the underlying Happisburgh Till (see Figure 4). Further north within zone SZ-Tr2 the décollement probably occurs at much deeper structural level (i.e. below the exposed coastal section) within the chalk bedrock.

Evidence for glacitectonism having penetrated into the underlying bedrock is provided by the thruststacked rafts of chalk and pre-glacial Wroxham Crag Formation within zone SZ-Tr3 (Figure 4). The style of faulting and large-scale folding which accompanied raft emplacement is consistent with their accretion having occurred in an ice-marginal to sub-marginal setting in response to ice-push from the north. Detachment, transport and emplacement of the rafts may have accompanied the upright folding in zone SZ-Tr2, hence marking the location of the ice margin during this stage of the evolution of the 'Cromer Ridge'. The distance travelled by the chalk rafts remains uncertain. Palaeontological data presented by Burke et al. (2009) indicates that the chalk forming the rafts is derived locally, implying that the southwards transport distance from the site of detachment was relatively short; perhaps less than a few hundred metres. Burke et al. (2009) and Vaughan-Hirsch et al. (2011) concluded that the thrusts which form the base of these rafts probably formed at the base of a thick permafrost layer beneath the ice sheet, with the rafts representing detached fragments of this frozen layer. The existence of permafrost in northern East Anglia prior to, and during the Middle Pleistocene glaciation is well-established (Rose and Allen, 1977; West, 1980; Fish et al., 1998; Briant et al., 1999; Whiteman, 2002). It is possible that the base of the permafrost layer controlled the location of the basal décollement within the chalk. The presence of this relatively impermeable permafrost horizon beneath North Sea ice would have acted as an impermeable barrier providing a focus for subglacial meltwater flow. The introduction of pressurised meltwater along the propagating basal décollement, via pre-existing planes of weakness such as joints and bedding, would have not only facilitated movement along this major structure, but may have induced 'thrustgliding' and the detachment of the much longer thrust-bound slabs of sediment (c.f. Davis et al., 1984; van Gijssel, 1987; Nieuwland et al., 2000; Andersen et al., 2005) which characterise zones SZTr3 and SZ-Tr4 (Figure 4).

The structurally lower part of zone SZ-Tr4 is dominated by largely concentric, buckle-style folds which record approximately $5 \%$ shortening of the glacigenic sequence. In the structurally higher parts of the zone, the sedimentary sequence has been thickened by tight to isoclinal folds and thrusts. The relatively open-style of folding, overlain by isoclinal folds and low-angle thrusting represents a vertical transition within zone SZ-Tr4 from proglacial to sub-marginal deformation (Van der Wateren, 1995), suggesting that the ice margin had once again retreated further to the north during the construction of the 'Cromer Ridge'. Further northwards within SZ-Tr4, beyond approximately $4000 \mathrm{~m}$, relicts of the detachments and isoclinal folds are preserved but variably disrupted by over-turned and highly-ductile soft-sediment folding that is consistent with subglacial overriding of the sediment pile (c.f. Van der Wateren, 1995; Evans et al., 2005; Phillips et al., 2008). The presence of flame-like and diapiric soft-sediment fold structures also indicate a switch to elevated porewater conditions with late-stage drainage of the subglacial bed indicated by the presence of vertical diapiric structures and sand-filled fractures interpreted as hydrofractures. The 
Lee, J.R., Phillips, E., Booth, S.J., Rose, J., Jordan, H.M., Pawley, S.M., Warren, M., Lawley, R.S. 2013. A polyphase glacitectonic model for ice-marginal retreat and terminal moraine development: the Middle Pleistocene British Ice Sheet, northern Norfolk, UK. Proceedings of the Geologists' Association, 124, 753-777. PRE-PROOF ACCEPTEF MANUSCRIPT.

absence of shear-related structures from the diapirs and hydrofractures implies that forward motion of the ice in this zone had ceased.

The progressive increase in the ductile nature of the deformation from south to north across the structural zones identified within Domain 2 can be used to infer a corresponding increase in porewater content within the sediment pile. Although this may reflect a primary variation in the porewater content of the glacial and pre-glacial sequence prior to deformation, it is likely that increasing volumes of meltwater were being produced as the A6 North Sea ice front retreated northwards. This increase in meltwater production during retreat could have directly resulted in an increase in the relative saturation of the sediment pile during the deformation responsible for the construction of the 'Cromer Ridge'. This temporal increase in porewater content of the sediments during deformation is reflected in the style of glacitectonism: i.e. zone SZ-Tr1 (south), relatively 'dry' resulting in high-angle brittle thrusting; zones SZ-Tr3 and SZ-Tr4 (south), relatively 'wet' facilitating ductile folding, and the detachment of longer slabs of sediment during thrusting; and SZ-Tr4 (north) highly diapiric and flame-like folding with water-escape structures.

In summary, deformation within Domain $2 \mathrm{~b}$ was clearly diachronous with the construction of the 'Cromer Ridge' accompanying the progressive retreat northwards of the A6 North Sea ice lobe (Figure 12; Table 3). The evolution of this complex landform can be summarised by the following stages: ice-marginal to proglacial thrusting (zone SZ-Tr1) associated within initial-still stand of the ice margin after its initial retreat across Domain 1 (Stage 3); further northward retreat of the ice margin to Overstrand accompanied by proglacial thrusting and upright folding (zone SZ-Tr2), and the ice-marginal to sub-marginal detachment and accretion of bedrock rafts (zone SZ-Tr3) (Stage 4); (c) further retreat of the ice-front accompanied by the increasing input of meltwater into the sediment pile leading to more ductile proglacial buckle folding (zone SZ-Tr4 - lower) (Stage 5); (d) minor readvance of the ice margin and low-angle thrusting and isoclinal folding of sediment pile (zone SZTr4 - upper / north) (Stage 6); rapid overriding of Stage 6 deposits and folding under elevated porewater conditions (Zone SZ-Tr4 - upper / north) (Stage 7); cessation of forward motion of the ice margin, stagnation, loading and de-watering of the sediment pile (Zone SZ-Tr4 - upper / north) (Stage 8); sub-marginal accretion of low-angle thrust blocks and isoclinal folding at the Roman Camp (Stage 9); forward motion ceases, loading and dewatering of the sediment pile (based on a published account of a temporary section on the northwest outskirts of Cromer (c.f. Banham, 1971).

\subsubsection{Domain 3 - Ice-marginal to sub-marginal glacitectonism}

The most prominent landforms developed within Domain 3 are Beeston and Skelding hills. The glacitectonised sequence within these landforms records two main phases of deformation. The first phase resulted in the thrust-stacking of the Happisburgh, Walcott and Bacton Green tills with the pre-glacial Wroxham Crag Formation. Well-developed easterly verging folds and east/southeastdirected thrust and ductile shears identified within this sequence, in particular the mélange facies of the Bacton Green Till, formed during the easterly-directed A5 advance of Lee et al. (2011a) (Table 1). These early structures were deformed during a later, southerly-directed deformation event which accompanied the emplacement of a large chalk raft (Figure 10) into this already poly-deformed sedimentary sequence. Consequently, the internal structure and geomorphology of Skelding Hill has led to this dome-shaped hill having been interpreted as a relict fragment of a former thrustmoraine (Stage 12). Several other similar shaped hills occur along the coast and slightly inland, including Muckleborough Hill (Weybourne), Beeston Hill (Sheringham), Incleborough and Wood hills (East Runton), and Arbor, Stone and Lighthouse hills (Cromer), for which a similar origin is suggested. 
Lee, J.R., Phillips, E., Booth, S.J., Rose, J., Jordan, H.M., Pawley, S.M., Warren, M., Lawley, R.S. 2013. A polyphase glacitectonic model for ice-marginal retreat and terminal moraine development: the Middle Pleistocene British Ice Sheet, northern Norfolk, UK. Proceedings of the Geologists' Association, 124, 753-777. PRE-PROOF ACCEPTEF MANUSCRIPT.

The southerly-directed deformation recorded by the sediments within Skelding Hill is consistent with ice advancing from the north (A6). However, the preservation of this distinct landform indicates that it has not been overridden and was formed in response to a minor readvance of the A6 North Sea ice lobe during its retreat northwards after it had pulled back from the 'Cromer Ridge'. The relationship of the southerly directed minor thrusting at Weybourne Town Pit to the more complex and much larger scale deformation observed at Skelding Hill is uncertain. Thrusting at Weybourne Town Pit possibly occurred in an ice-marginal to sub-marginal setting leading to the stacking of relatively 'dry' slices of Bacton Green and Weybourne Town tills (Van der Wateren, 1995, 2005; Evans and Twigg, 2002). No obvious landform (moraine) has been recognised associate with this thrusted sequence. Consequently, one possible scenario is that thrusting at Weybourne Town Pit occurred as the A6 North Sea ice lob retreated relatively rapidly northwards after 'unzipping' from the 'Cromer Ridge' and prior to the readvance responsible for the construction of the Skelding Hill thrust-block moraine.

Deformation structures within the succession at Stody are also considered to have initially developed in a sub-marginal setting where rafts of proglacial outwash sediment were imbricately stacked along low angle thrust faults. Continued glacier advance over the site resulted in the deposition of the overlying Weybourne Town Till Member, which truncated the gravel slabs, developed a ductile shear zone and incorporated the outwash deposits into the overlying till. The ductile deformation style within the relatively coarse-grained deposits is testament to high porewater pressures, likely facilitated by the till forming an aquicluide and upward-directed groundwater flow towards the glacier margin being impeded (Boulton and Caban, 1995). The style of deformation within the succession first being brittle thrusting, and subsequently being attenuated subglacially records a progression from proglacial to sub-marginal glacitectonic style.

\subsection{Polyphase evolution of the "Cromer Ridge"}

Glacitectonic and geomorphological evidence portrays a complex picture of active ice-marginal retreat in North Norfolk during the Middle Pleistocene (Figures 12, 13, 14 and Table 3). The Bacton Green Till was deposited by an earlier oscillation (A4) of the North Sea lobe of the British Ice Sheet into north Norfolk and consists of a complex sequence of subglacial and subaqueous diamictons (Lunkka, 1994; Lee and Phillips, 2008). As the margins of the North Sea lobe of ice retreated northwards, north Norfolk was crossed by a lobe of British ice that crossed the region broadly from west to east (Perrin et al., 1979; Ehlers et al., 1987; Scheib et al., 2011). This A5 advance led to the development of a variably pervasive glacitectonite which partly remobilised the underlying Bacton Green Till, and in places deposited a highly chalky till of western provenance, called the Weybourne Town Till (Dhonau and Dhonau, 1963; Banham and Ranson, 1965; Banham, 1966; Ehlers et al., 1987; Hart, 2007; Lee and Phillips, 2008; Phillips et al., 2008). The highly ductile soft-sediment style of deformation indicates that pore-water content between A4 and A5 was largely maintained, suggesting that the two events followed in quick succession (Lee and Phillips, 2008).

As the margins of the western ice (A5) retracted from northeast Norfolk, there was a further readvance into the region by the North Sea ice lobe from the north (A6) which deposited the northernderived facies of the Weybourne Town Till (Stage 1; Figure 12). Limited evidence for deformation of the underlying sediment pile implies that the advance phase of A6 was characterised by enhanced basal sliding with ice largely decoupled from its bed. This is possibly indicative of fast flow or surge conditions. The maximum known extent of the $\mathrm{A} 6$ advance is depicted by the southern margins of Domain 1 (Figure 14a) and highlights that ice from this advance extended much further to the south than the previously accepted limit (southern margin of Domain 2) indicates (c.f. Straw, 1973; Boulton 
Lee, J.R., Phillips, E., Booth, S.J., Rose, J., Jordan, H.M., Pawley, S.M., Warren, M., Lawley, R.S. 2013. A polyphase glacitectonic model for ice-marginal retreat and terminal moraine development: the Middle Pleistocene British Ice Sheet, northern Norfolk, UK. Proceedings of the Geologists' Association, 124, 753-777. PRE-PROOF ACCEPTEF MANUSCRIPT.

et al., 1984; Hart, 1990; Lee et al., 2004; Pawley et al., 2005). Northwestwards retreat of the ice margin across Domain 1 and Domain 2a (Figure 14b) by ice that was 'weakly' coupled to its bed, led to localised ice-marginal and proglacial tectonism and the formation small terminal moraines and thrust-tip ridges (Stage 2) (Figure 12). The progressive step-like retreat of the moraines is characteristic of active retreat of a thinning ice mass (c.f. Evans et al., 2002; Evans, 2005). Deposition of glacilacustrine deposits occurred between the moraines indicates the development of localised proglacial lake basins and the availability of meltwater during retreat.

Stage 3 is marked by the southern edge of Domain $2 b$ - the main element of the 'Cromer Ridge' (Figure 14c). Domain $2 b$ moraine ridges differ from those within Domain 2a, indicating that whilst ice within the west of the study area was withdrawing northwestwards into the Glaven Valley, an ice-front developed broadly west-east within Domain $2 b$ to the east between Sheringham and Trimingham. Doman $2 \mathrm{~b}$ is composed of an imbricate fan that displays a deeper style of tectonism compared to Domain 1 and Domain 2a, with more steeply-inclined thrust faulting and shorter thrust blocks (Trimingham SZ-Tr1). These structural characteristics imply a high-friction, dry, substrate (c.f. Andersen et al., 2005) with strong ice-bed coupling and therefore a marked change in bed conditions from Domain 1. The structural form is reminiscent of a composite moraine produced at an icemarginal still-stand (c.f. Krüger, 1993). Within the east of the study area, the transition of deformation styles between Domain 1 and $2 \mathrm{~b}$ is not easily attributed to continued active retreat (previous stage). Instead, substantial thickening of the ice mass and steepening of the ice margin during a re-advance is invoked to produce this much larger morainic feature. A further northwards retreat of the ice margin to Overstrand led to the initiation of sub-marginal detachment, transportation and deposition of the Chalk glacitectonic rafts (SZ-Tr3) and associated deformation of SZ-Tr2 (Stage 4), plus the continued development of low-angle thin-skinned detachments and the development of a lower set of open buckle-style folds (SZ-Tr4 - lower) (Stage 5). The transition between these structural styles can be equated to sub-marginal to proglacial tectonism produced by an ice-margin that was variably coupled to its bed. The final recognisable phases of deformation occur along the northern edge of Domain $2 b$ ('Cromer Ridge'). They relate to the upper deformed zone of SZ-Tr4 at Overstrand and the low-angle thrusts of the Roman Camp, West Runton. The lowangle thrusting and detachment of longer thrust blocks within SZ-Tr4 (south / upper) typify submarginal styles of 'thin' glacitectonism (Van der Wateren, 1995) (Stage 6) and record a progressive northwards retreat of the Stage 5 ice margin. A subsequent re-advance and overriding of the northern end of SZ-Tr4 led to the overprinting of Stage 6 sub-marginal structures by a more pervasive soft-sediment structure imparted by subglacial to sub-marginal deformation (Stage 7). Truncation of these structures by diapirs and hydrofractures which are un-sheared indicates a cessation of forward motion of the ice, although whether dewatering of the subglacial bed either facilitated or drove ice stagnation remains unclear (Stage 8). A similar sub-marginal and subglacial retreat pattern to SZ-Tr4 is also indicated further north within Domain $2 b$, with sub-marginal thrusting and folding at the Roman Camp, West Runton (Stage 9), and highly diapiric and fluid-rich styles of soft-sediment deformation recognised by Banham (1971) within a temporary section on the northwest outskirts of Cromer (Stage 10). The highly ductile style of folding, coupled with the presence of water escape and diapiric structures during stages 7-10 indicate dramatically increased meltwater production and a variably re-hydrated sediment pile.

Stage 11 corresponds to a major retreat of ice from the northern margin of Domain 2 ('Cromer Ridge') in the east of the study area, northwards across Domain 3 to an area probably to the north of the present coastline. The presence of minor low-angle thrusting within pre-existing sediments (e.g. Weybourne Town Pit, Stody Pit) indicates that at least locally, ice was thinly coupled its bed. However, the paucity of tectonic structures relating to A6 displayed within coastal sections between East Runton and Weybourne (c.f. Dhonau and Dhonau, 1963; Pawley et al., 2004; Hart, 2007; Phillips 
Lee, J.R., Phillips, E., Booth, S.J., Rose, J., Jordan, H.M., Pawley, S.M., Warren, M., Lawley, R.S. 2013. A polyphase glacitectonic model for ice-marginal retreat and terminal moraine development: the Middle Pleistocene British Ice Sheet, northern Norfolk, UK. Proceedings of the Geologists' Association, 124, 753-777. PRE-PROOF ACCEPTEF MANUSCRIPT.

et al., 2008; Phillips and Lee, this volume) indicates that this occurrence is perhaps an exception, and that ice was largely decoupled from its substrate. The simplest explanation of this stage is one of a major ice-marginal surge (i.e. Stage 7) followed by large-scale active retreat and stagnation (i.e. Stages 8-9). Highly localised till deposition during this advance (i.e. Stage 7) is indicated by the deposition of a highly-chalky northerly-derived facies of the Weybourne Town Till Member along the coast between Weybourne and Sheringham (Phillips and Lee, 2013), initial till deposition at Weybourne Town Pit and Stody (this study). Common soft-sediment deformation structures, hydrofractures and diapirs demonstrate the spatial and temporal variability of porewater content within the substrate, and this ultimately, may have facilitated surge and stagnation patterns of behaviour.

In the Glaven Valley, situated within the west of the study area, ice extended much further to the south indicating an east-to-west 'unzipping' of the ice from the 'Cromer Ridge' during mass-wastage (Figure 14d). At its maximum extent within the Glaven Valley, ice remained coupled to its bed, resulting in the thrusting of gravel sheets and deposition of the northern facies of the Weybourne Town Till along the northern flank of the ridge at Stody. During the initial withdrawal of ice, proglacial drainage is likely to have drained through the 'Briston Gap', a topographic low within the crest of the 'Cromer Ridge', and drained southwards incising the modern headwaters of the River Bure. The precise age of the 'Briston Gap' is, however, speculative as it could have formed either as soon as the ice reached its maximum extent of during retreat. Further withdrawal of ice from the Glaven Valley occurred during several phases that correspond to progressive thinning (wasting) of the ice, and formation of the Kelling (Stage 11i) and Salthouse (Stage 11ii) outwash sandurs at progressively lower elevations. A still-stand or minor readvance (Stage 12), broadly aligned along the line of the modern coastline, is indicated by the Beeston Hill and Skelding Hill thrust block moraine (c.f. West, 1957) and may be continuous with similar landforms at Ingleborough Hill, West Runton (TG 189 423) and Wood Hill, East Runton (TG 195 429). The thrusting and chalk rafting at Skelding Hill (Stage 12) indicate strong coupling between the glacier and its bed, implying that the bed was relatively dry compared to Stage 11 .

Overall, the pattern of ice-marginal recession from its maximum position located to the south of the 'Cromer Ridge' is reminiscent of 'active ice-marginal retreat'. Comparable patterns of active retreat have been advocated for the decay of several major Pleistocene ice streams occupying basinal or shelf areas (e.g. Stokes et al., 2006; Thomas and Chiverrell, 2007; Clark et al., 2012). A similar scenario is envisaged here where the present area of north Norfolk formed the ice-marginal zone of fast-flowing ice that extended southwards down the North Sea basin from northeastern Britain.

\subsection{The age of the glaciation and glacial deformation}

The absolute chronology of the A6 event in north Norfolk is a controversial issue with several different models indicating glaciation during the Anglian glaciation (Lunkka, 1994; Banham et al., 2001; Pawley et al., 2008; Preece et al., 2009) or during a later Middle Pleistocene glaciation possibly equivalent to MIS 6 (Saalian) (Straw, 1973; Hamblin et al., 2000, 2005; Rose, 2009). A detailed critique of the evidence and arguments behind this debate is beyond the scope of this paper (see Rose, 2009 for an overview of this debate) although 'dated' stratigraphic levels within the glacitectonised succession enable a chronostratigraphy to be applied to parts of the succession. Structural evidence presented here demonstrates that glacitectonism within Domains 1 and 2 occurred contemporaneously with deposition of the lower (structural) levels of the Briton's Lane Formation. Within Briton's Lane Quarry (Domain 2) - the stratotype for the deposit (Pawley et al., 2005), these sands and gravels have been dated to MIS 12 by OSL (Pawley et al., 2008). Supporting evidence for this age is provided by an early MIS 11 (Hoxnian) age for organic deposits that infill an 
Lee, J.R., Phillips, E., Booth, S.J., Rose, J., Jordan, H.M., Pawley, S.M., Warren, M., Lawley, R.S. 2013. A polyphase glacitectonic model for ice-marginal retreat and terminal moraine development: the Middle Pleistocene British Ice Sheet, northern Norfolk, UK. Proceedings of the Geologists' Association, 124, 753-777. PRE-PROOF ACCEPTEF MANUSCRIPT.

apparent kettle-hollow within deformed Briton's Lane Formation deposits at Sidestrand (Hart and Peglar, 1990; Preece et al., 2009). The age of the sediments and landforms within Domain 3 is more subjective. The simplest explanation, and that largely favoured here, is that Domain 3 records a further stage of ice-marginal wastage and retreat from Domain 2 - thus an Anglian MIS 12 age (Banham et al., 2001; Hoare et al., 2009; Preece et al., 2009). However, to-date no absolute dates have been produced that directly date glacigenic materials in this domain so this assertion is at best equivocal, and it remains a possibility that elements of Domain 3 could be younger. This is particularly the case for the Stage 12 thrust-block moraines at Skelding and Beeston hills. Whilst these moraines clearly fit into the glacitectonic model presented above, the comparatively drier style of glacitectonic deformation associated with moraine formation identifies a fundamental change in substrate drainage with the immediately preceding stages (high to elevated porewater conditions). This implies a significant hiatus between Stages 11 and 12 during which a regional-scale drying / draining of the substrate occurred.

\subsection{Morphostratigraphic interpretations of the glacial history of north Norfolk}

The landforms of Domains 2 and 3, located within the region between Blakeney and Trimingham (Figure 2a), have long attracted attention because of their similarity with kames, ice contact slopes and outwash plains of modern glacial landsystems. This attribute, and particularly their welldeveloped nature or 'freshness', has been considered to be of morphostratigraphic significance and relevant to the interpretation of the age of the glaciation in which they formed, following from the concept of 'Older Drift' and 'Newer Drift' (cf. Wright, 1937). The position of some of these landforms is shown on Figure $2 \mathrm{~b}$ and on Figure 15 which is an oblique angle DSM of the region viewed from the WNW. Glacigenic landforms visible include steep-sided 'glacitectonic' hillocks such as Muckleburgh Hill, Skelding Hill and Beeston Hill, as well as small irregular gravel mounds in the Glaven Valley interpreted as kames. The Cromer Ridge is the dominant feature, and the Kelling and Salthouse outwash fans show as well developed surfaces standing above the adjacent Glaven Valley and coastal fringe. The sharp, steep, crenellate slope around the western margins of the Kelling and Salthouse fans, and the northern margin of these fans and the Cromer Ridge is what has been interpreted as the ice-contact slope.

Straw (1960) first speculated that these landforms are of glacigenic origin, but acknowledged that the deposits of which they are composed are not the same materials as those deposited during the last glaciation (Devenisan, MIS 2). He therefore suggested that the kames and ice-contact slopes were formed by differential erosion relating to the texture of the materials. This interpretation was refuted by Sparks and West (1964) who suggested that the kames and ice-contact slopes are original glacigenic landforms, although 'freshened' in places by agricultural practices (e.g. ploughing) and spring-sapping and accentuated by a variable substrate geology. Sparks and West also identified a linear body of sand and gravel south of Blakeney which they interpreted as an esker, an interpretation that survives until the present (Gray, 1997; Moorlock et al., 2002; Gale and Hoare, 2007). However, Sparks and West (1964) recognised that the glacigenic deposits in the area were not formed during the last glaciation (MIS 2), and proposed that the landforms were formed during an earlier glacial stage, thus discrediting the morphostratigraphic concept of Newer and Older Drift. To support this contention they drew analogy with similar landforms in northern Europe that were also attributed to a glaciation earlier then the last. In recent years there has been much debate about the glacial history of East Anglia with a traditional concept advocating a single glaciation prior to the last (MIS 2) (Perrin et al., 1979; Bowen et al., 1986) and a multiphase glacial history with glacial deposits or landforms attributed to most of the Marine Isotope cold stage (MIS 16, MIS 12, MIS 10, MIS 6 and MIS 2) (Hamblin et al., 2005; Rose, 2009). Most of the issues of this debate are considered elsewhere (see Preece et al., 2009 and Rose, 2009 for overviews), but one of the critical 
Lee, J.R., Phillips, E., Booth, S.J., Rose, J., Jordan, H.M., Pawley, S.M., Warren, M., Lawley, R.S. 2013. A polyphase glacitectonic model for ice-marginal retreat and terminal moraine development: the Middle Pleistocene British Ice Sheet, northern Norfolk, UK. Proceedings of the Geologists' Association, 124, 753-777. PRE-PROOF ACCEPTEF MANUSCRIPT.

lines of evidence for multiphase glaciation has been the use of morphostratigraphy. This has been employed based upon the form of the landforms as evidence for a separate glaciation attributed to MIS 6, again in line with the proposals of Sparks and West (1964). In addition to the morphostratigraphic evidence, Hamblin et al. $(2000,2005)$ have proposed that the Briton's Lane Sands Formation sands and gravels were deposited during MIS 6, by an ice sheet with a Scandinavian source. This is due to the in-situ presence of provenanced Scandinavian clasts and an inferred correlation with glacial deposits in East Yorkshire and County Durham that reportedly also contain erratics of Scandinavian provenance. The glacitectonic analysis presented here refutes the lithological evidence of Hamblin et al. $(2000,2005)$ because of the integration of the Briton's Lane Sands Formation sands and gravels into the glacitectonic architecture of the region. One possibility is that stages 11-12 could be separate from 1-10 because of the different substrate drainage conditions. However, there is no independent evidence to support this assertion and substrate drainage in glacial environments can change rapidly.

Despite this, the morphostratigraphic evidence still remains equivocal. The problem remains that if the landforms attributed to a glacigenic origin were formed at the time of the glacitectonism, which is attributed to MIS 12 (assuming the tectonism of stages 11 and 12 are not separate from 1 to 10 ), then they are the oldest glacigenic landforms in the British Isles and possibly northern Europe, a possibility that is unlikely in view of the moist, active geomorphic regime of Britain and the highly erodible material of the region. The DSM of Figure 15 does appear to offer new information that contributes to the problem. Examination of the terrain between the north slope of the Cromer Ridge and the North Sea, shows a clearly-defined set of short valleys draining northwards to be truncated by the present coastline. The repetitive morphology of the valley networks suggests that the northern 'ice-contact' slope of the Cromer Ridge is indeed an erosional form as proposed by Straw (1960), and that the sharp break in slope at the head of the valleys is a function of the lithology of the sediments with better drained sorted sediments and sandy diamictons overlying the clay and silt rich chalky diamicton that forms the valley bottoms. Survival of the Cromer Ridge as a moraine can be explained by the size of the original feature although it is clear that there is no clear relationship between the glacitectonics and the modern morphology of the landform. Likewise the surfaces of the Kelling and Salthouse outwash fans can survive as a function of their low relief, with dissection along the fan margins and along the main drainage axis which is now the upper NNE-SSW trending reach of the River Glaven. Nevertheless there still remain the irregular distribution of small hills (kames) in the lower Glaven valley and the esker at Blakeney. It could be possible that the esker ridge and kame hillocks survive as a consequence of being composed of well drained coarse grained materials, but this is not the case with the kame hillocks that are composed of both fine-grained diamictons and sands and gravels, and an origin determined by a chaotic distribution of ice-contact slopes in a decaying, stagnant glacier remains a most likely explanation for their origin.

Clearly, the bulk of the evidence points to a single glaciation during which the complex patterns of advance and retreat contributed to a glacitectonic model for the glacial history of north Norfolk, but issue associated with the survival of a small number of landforms remain and may have morphostratigraphic significance as proposed by Sparks and West (1964), Hamblin et al. (2000, 2005) and Rose (2009).

\section{Conclusions}

- The examination of geomorphology, geology and glacitectonic structure within terminal moraines can reveal complex patterns of ice-marginal behaviour and glacier dynamics associated with the margins of former ice sheets. 
Lee, J.R., Phillips, E., Booth, S.J., Rose, J., Jordan, H.M., Pawley, S.M., Warren, M., Lawley, R.S. 2013. A polyphase glacitectonic model for ice-marginal retreat and terminal moraine development: the Middle Pleistocene British Ice Sheet, northern Norfolk, UK. Proceedings of the Geologists' Association, 124, 753-777. PRE-PROOF ACCEPTEF MANUSCRIPT.

- Examination of the 'Cromer Ridge' moraine complex reveals a complex twelve-stage model of ice advance and retreat associated with the southwards extension and subsequent retreat of the North Sea lobe of the British Ice Sheet from northern East Anglia during the Middle Pleistocene. Critically, the presence of moraine ridges and thrust-tip moraines to the south of the 'Cromer Ridge' indicates that ice extended much further to the south across the region than previously recognised.

- Retreat of the North Sea lobe from its maximum southern extent resulted in the 'thin-skinned' glacitectonic deformation of the pre-existing sediment pile by sub-marginal and proglacial pushing and thrusting. Vertical and lateral variability and superimposition of structural styles record multiple phases of ice-marginal oscillation and associated with different flow dynamics including possible surge advance, normal advance, still-stand, active retreat, and rapid retreat.

- The development of specific styles of structural evidence are related to specific ice-marginal dynamics which in-turn, are strongly influenced by substrate drainage. For example, 'shallow' thin-skinned glacitectonic features (low angle thrusting, isoclinal folding, long thrust-blocks) correspond to surge-like behaviour and high basal water content. By contrast, 'deeper' thinskinned glacitectonic structures and the construction of steeper faulting and shorter thrustblocks is more akin to drier substrate conditions.

\section{Acknowledgments}

The authors wish to acknowledge several colleagues who were also involved in the geological survey of the Cromer and Aylsham districts most notably Richard Hamblin, Anna Harrison, Holger Kessler and Brian Moorlock. Phil Wilby, Richard Haslam and Rodger Connell are thanked for comments on an earlier version of the manuscript. Jaap van der Meer, Sven Lukas and lan Candy are warmly thanked for their constructive reviews and comments which have greatly helped to improve the manuscript. We also wish to acknowledge the friendly discussions and debates we've enjoyed over the years including several individuals and delegates of the QRA Glacitectonics Workshop (2011) especially: Helen Burke, Peter Banham, Dave Evans, Richard Hamblin, Jane Hart, Brian Moorlock, Julian Murton, Dave Roberts, Jaap van der Meer, David Vaughan-Hirsch and Richard Waller. BGS authors publish with the permission of the Executive Director of the British Geological Survey (NERC).

\section{References}

Andersen, L.T., Hansen, D.L., Huuse, M. 2005. Numerical modelling of thrust structures in unconsolidated sediments: implications for glacitectonic deformation. Journal of Structural Geology 27, 587-596.

Baden-Powell, D.F.W., 1948. The chalky boulder clays of Norfolk and Suffolk. Geological Magazine 85, 279-296.

Bakker, M.A.J., 2004. The internal structure of Pleistocene push moraines: a multidisciplinary approach with emphasis on ground-penetrating radar. $\mathrm{P}$ 
Lee, J.R., Phillips, E., Booth, S.J., Rose, J., Jordan, H.M., Pawley, S.M., Warren, M., Lawley, R.S. 2013. A polyphase glacitectonic model for ice-marginal retreat and terminal moraine development: the Middle Pleistocene British Ice Sheet, northern Norfolk, UK. Proceedings of the Geologists' Association, 124, 753-777. PRE-PROOF ACCEPTEF MANUSCRIPT.

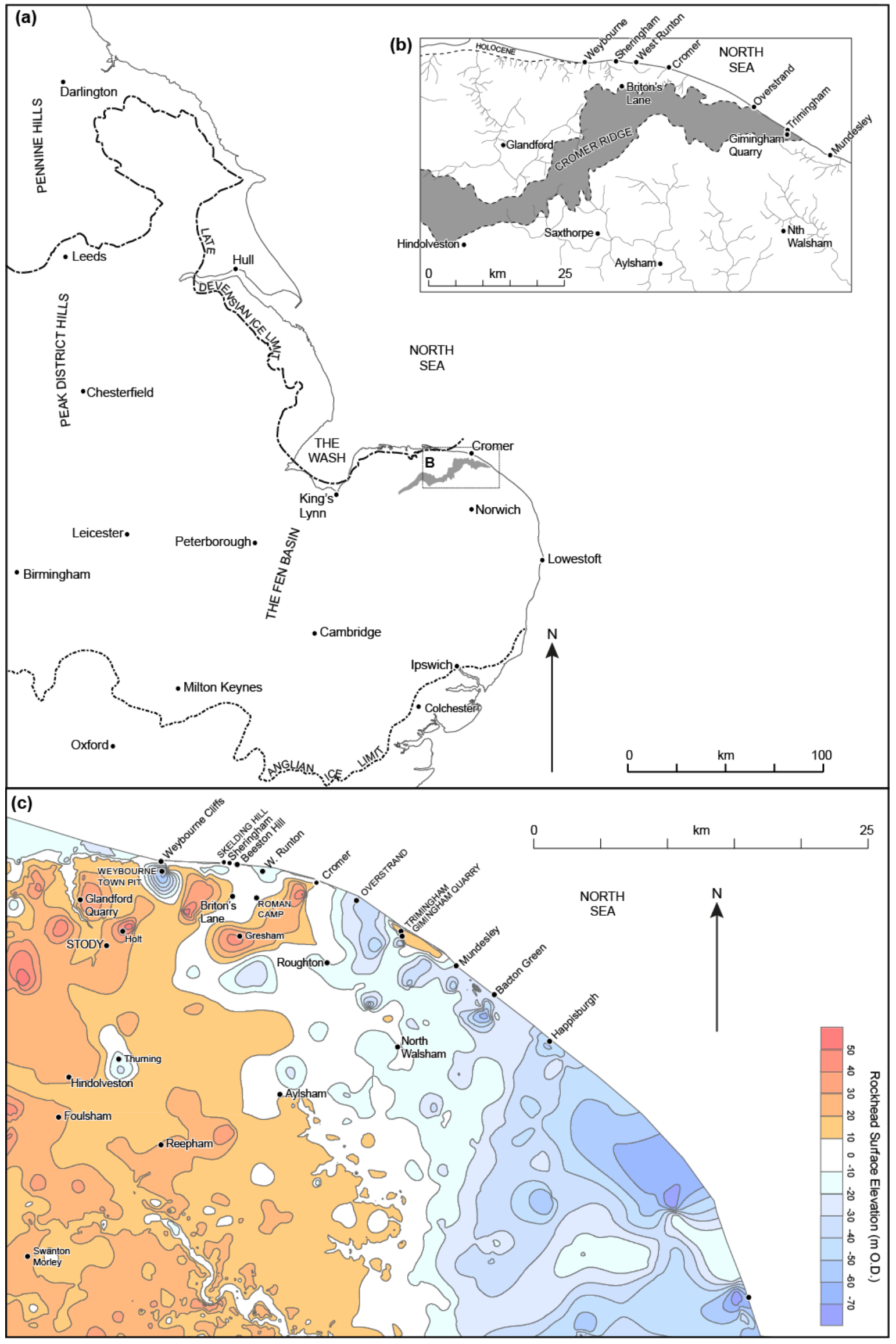

Figure 1 
Lee, J.R., Phillips, E., Booth, S.J., Rose, J., Jordan, H.M., Pawley, S.M., Warren, M., Lawley, R.S. 2013. A polyphase glacitectonic model for ice-marginal retreat and terminal moraine development: the Middle Pleistocene British Ice Sheet, northern Norfolk, UK. Proceedings of the Geologists' Association, 124, 753-777. PRE-PROOF ACCEPTEF MANUSCRIPT.

ublished PhD thesis, Queen Mary, University of London.

Banham, P.H., 1965. Pleistocene deposits at Weybourne: New data. Proceedings of the Geologists' Association 76, 77-81.

Banham, P.H., 1966. The significane of till pebble lineations and their relation to folds in two Pleistocene tills at Mundesley, Norfolk. Proceedings of the Geologists' Association 77, 469-474.

Banham, P.H., 1968. A preliminary note on the Pleistocene stratigraphy of northeast Norfolk. Proceedings of the Geologists' Association 79, 507-512.

Banham, P.H., 1970. Notes on Norfolk coastal sections, In: Boulton, G.S. (Ed.), Field Guide, Norwich. Quaternary Research Association, Cambridge, pp. 39-41.

Banham, P.H., 1971. Temporary exposure in the drift near Cromer. Bulletin of the Geological Society of Norfolk 19, 35-37.

Banham, P.H., 1975. Glacitectonic structures: a general discussion with particular reference to the contorted drift of Norfolk, In: Wright, A.E., Moseley, F. (Eds.), Ice Ages: Ancient and Modern. Seel House Press, Liverpool, pp. 69-84.

Banham, P.H., 1977a. Glacitectonites in till stratigraphy. Boreas 6, 101-105.

Banham, P.H., 1977b. Stop 3. Briton's Lane Gravel Pit, In: West, R.G. (Ed.), East Anglia. Guidebook for Excursions A1 and C1, INQUA X Congress 1977. Geo Abstracts, Norwich, pp. 28-29.

Banham, P.H., 1988a. Polyphase glacitectonic deformation in the contorted drift of Norfolk, In: Croot, D. (Ed.), Glacitectonics: Forms and Processes. Balkema, Rotterdam.

Banham, P.H., 1988b. Thin-skinned glacitectonic structures, In: Croot, D.G. (Ed.), Glacitectonics, forms and processes. Balkema, Rotterdam, pp. 21-26.

Banham, P.H., Davies, H., Perrin, R.M.S., 1975. Short field meeting in North Norfolk; 19-21 October 1973. Proceedings of the Geologists' Association 86, 251-258.

Banham, P.H., Gibbard, P.L., Lunkka, J.P., Parfitt, S.A., Preece, R.C., Turner, C., 2001. A critical assessment of 'a new glacial stratigraphy for eastern England. Quaternary Newsletter 93, 5-14.

Banham, P.H., Ranson, C.E., 1965. Structural study of the Contorted Drift and disturbed chalk at Weybourne, north Norfolk. Geological Magazine 102, 164-174.

Benediktsson, Í.Ö., IngÓLfsson, Ó., Schomacker, A., Kjær, K.H., 2009. Formation of sub-marginal and proglacial end moraines: implications of ice-flow mechanism during the 1963-64 surge of Brúarjökull, Iceland. Boreas 38, 440-457.

Benediktsson, Í.Ö., Schomacker, A., Lokrantz, H., Ingólfsson, Ó., 2010. The 1890 surge end moraine at Eyjabakkajökull, Iceland: a re-assessment of a classic glacitectonic locality. Quaternary Science Reviews 29, 484-506. 
Lee, J.R., Phillips, E., Booth, S.J., Rose, J., Jordan, H.M., Pawley, S.M., Warren, M., Lawley, R.S. 2013. A polyphase glacitectonic model for ice-marginal retreat and terminal moraine development: the Middle Pleistocene British Ice Sheet, northern Norfolk, UK. Proceedings of the Geologists' Association, 124, 753-777. PRE-PROOF ACCEPTEF MANUSCRIPT.

Benn, D.I., Evans, D.J.A., 2010. Glaciers and Glaciation. Hodder Education, London.

Benn, D.I., Lukas, S., 2006. Younger Dryas glacial landsystems in North West Scotland: an assessment of modern analogues and palaeoclimatic implications. Quaternary Science Reviews 25, 2390-2408.

Bennett, M.R., 2001. The morphology, structural evolution and significance of push moraines. EarthScience Reviews 53, 197-236.

Boulton, G.S., Caban, P. 1995. Groundwater flow beneath ice sheets, Part II. Its impact on glacier tectonic structures and moraine development. Quaternary Science Reviews 14, 563-587.

Boulton, G.S., Cox, F., Hart, J., Thornton, M., 1984. The glacial geology of Norfolk. Bulletin of the Geological Society of Norfolk 34, 103-122.

Boulton, G.S., van der Meer, J.J.M., Beets, D.J., Hart, J.K., Ruegg, G.H.J., 1999. The sedimentary and structural evolution of a recent push moraine complex: Holmstrombreen, Spitsbergen. Quaternary Science Reviews 18, 339-371.

Boulton, G.S., Van Der Meer, J.J.M., Hart, J., Beets, D., Ruegg, G.H.J., Van Der Wateren, F.M., Jarvis, J., 1996. Till and moraine emplacement in a deforming bed surge -- an example from a marine environment. Quaternary Science Reviews 15, 961-987.

Bowen, Q.C., Rose, J., McCabe, A.M., Sutherland, D.G., 1986. Correlation of Quaternary glaciations in England, Ireland, Scotland and Wales, In: Sibrava, V., Bowen, Q.C., Richmond, G.M. (Eds.), Quaternary glaciations in the Northern Hemisphere. Quaternary Science reviews, pp. 299-340.

Briant, R.M., Rose, J., Branch, N.P., Lee, J.A., 1999. Pre-glacial Quaternary sediments from Trimingham, North Norfolk, England. Bulletin of the Geological Society of Norfolk 49, 15-47.

British Geological Survey, 2002. Cromer. England and Wales Sheet 131. Solid and Drift Geology, 1: 50,000. British Geological Survey, Keyworth, Nottingham.

British Geological Survey, 2013. Aylsham. England and Wales Sheet 147. Solid and Drift Geology, 1: 50,000. British Geological Survey, Keyworth, Nottingham.

Burke, H., Phillips, E., Lee, J.R., Wilkinson, I.P., 2009. Imbricate thrust stack model for the formation of glacitectonic rafts: an example from the Middle Pleistocene of north Norfolk, UK. Boreas 38, 620637.

Christoffersen, P., Tulaczyk, S., 2003. Signature of palaeo-ice-stream stagnation: till consolidation induced by basal freeze-on. Boreas 32, 114-129.

Clark, C.D., Gibbard, P.L., Rose, J., 2004. Pleistocene glacial limits in England, Scotland and Wales, In: Ehlers, J., Gibbard, P.L. (Eds.), Developments in Quaternary Science. Elsevier, pp. 47-82.

Clark, C.D., Hughes, A.L.C., Greenwood, S.L., Jordan, C., Sejrup, H.P. 2012. Pattern and timing of retreat of the last British-Irish Ice Sheet. Quaternary Science Reviews 44, 112-146. 
Lee, J.R., Phillips, E., Booth, S.J., Rose, J., Jordan, H.M., Pawley, S.M., Warren, M., Lawley, R.S. 2013. A polyphase glacitectonic model for ice-marginal retreat and terminal moraine development: the Middle Pleistocene British Ice Sheet, northern Norfolk, UK. Proceedings of the Geologists' Association, 124, 753-777. PRE-PROOF ACCEPTEF MANUSCRIPT.

Cox, F.C., Nickless, E.F.P., 1972. Some aspects of the glacial history of central Nofolk. Bulletin of the Geological Survey of Great Britain 42, 79-88.

Croot, D.G., 1987. Glaci-tectonic structures - a mesoscale model of thin-skinned thrust sheets. Journal of Structural Geology 9, 797-808.

Dahlen, F.A., Suppe, J., Davis, D.M., 1984. Mechanics of fold and thrust belts and accretionary wedges: Cohesive Coulomb Theory. Journal of Geophysical Research 89, 10087-10101.

Dhonau, T.J., Dhonau, N.B., 1963. Glacial structures on the North Norfolk coast. Proceedings of the Geologists' Association 74, 433-438.

Ehlers, J., Gibbard, P.L., Whiteman, C.A., 1987. Recent investigations of the Marly Drift of northwest Norfolk, England, In: Van der Meer, J.J.M. (Ed.), Tills and glacitectonics. Balkema, Rotterdam, pp. 3954.

Ehlers, J., Gibbard, P.L., Whiteman, C.A., 1991. The glacial deposits of northwestern Norfolk, In: Ehlers, J., Gibbard, P.L., Rose, J. (Eds.), Glacial deposits in Great Britain and Ireland. Balkema, Rotterdam, pp. 223-232.

Evans, D.J.A., 2005. Ice-marginal terrestrial landsystems: active temperate glacier margins, In: Evans, D.J.A. (Ed.), Glacial Landsystems. Arnold, London, pp. 12-43.

Evans, D.J.A., Clark, C.D., Rea, B.R., 2008. Landform and sediment imprints of fast glacier flow in the southwest Laurentide Ice Sheet. Journal of Quaternary Science 23, 249-272.

Evans, D.J.A., Hiemstra, J.F., 2005. Till deposition by glacier sub-marginal, incremental thickening. Earth Surface Processes and Landforms 30, 1633-1662.

Evans, D.J.A., Lemmen, D.S., Rea, B.R., 1999. Glacial landsystems of the southwest Laurentide Ice Sheet: modern Icelandic analogues. Journal of Quaternary Science 14, 673-691.

Evans, D.J.A., Rea, B.R., 1999. Geomorphology and sedimentology of surging glaciers: a land-systems approach. Annals of Glacilogy 28, 75-82.

Evans, D.J.A., Rea, B.R., 2005. Surging Glacier Landsystems, In: Evans, D.J.A. (Ed.), Glacial Landsystems. Hodder Arnold, London, pp. 259-288.

Evans, D.J.A., Thomson, S.A., 2010. Glacial sediments and landforms of Holderness, eastern England: A glacial depositional model for the North Sea Lobe of the British-Irish Ice Sheet. Earth-Science Reviews 101, 147-189.

Evans, D.J.A., Twigg, D.R., 2002. The active temperate glacial landsystem: a model based on Breidamerkurjökull and Fjallsjökull, Iceland. Quaternary Science Reviews 21, 2143-2177.

Evans, H.M., Lee, J.R., Riding, J.B., 2011. A thrust-stacked origin for inter-stratified till sequences: an example from Weybourne Town Pit, north Norfolk, UK. Bulletin of the Geological Society of Norfolk 61, 23-49. 
Lee, J.R., Phillips, E., Booth, S.J., Rose, J., Jordan, H.M., Pawley, S.M., Warren, M., Lawley, R.S. 2013. A polyphase glacitectonic model for ice-marginal retreat and terminal moraine development: the Middle Pleistocene British Ice Sheet, northern Norfolk, UK. Proceedings of the Geologists' Association, 124, 753-777. PRE-PROOF ACCEPTEF MANUSCRIPT.

Finlayson, A., Merritt, J., Browne, M., Merritt, J., McMillan, A., Whitbread, K., 2010. Ice sheet advance, dynamics, and decay configureurations: evidence from west central Scotland. Quaternary Science Reviews 29, 969-988.

Fischer, U.H., Mair, D., Kavanaugh, J.L., Willis, I., Nienow, P., Hubbard, B., 2011. Modelling ice-bed coupling during a glacier speed-up event: Haut Glacier d'Arolla, Switzerland. Hydrological Processes $25,1361-1372$.

Fish, P.R., Whiteman, C.A., Moorlock, B.S.P., Hamblin, R.J.O., Wilkinson, I.P., 2000. The glacial geology of the Weybourne area, north Norfolk: a new approach. Bulletin of the Geological Society of Norflok 50, 21-45.

Fleming, E.J., Stevenson, C.T.E., Petronas, M.S. 2013. new insights into the deformation of a Middle Pleistocene glaciotectonised sequence in Norfolk, England through magnetic and structural analysis. Proceedings of the Geologist's Association, this volume.

Gale, S.J., Hoare, P.G., 2007. The age and origin of the Blakeney esker of north Norfolk: implications for the glacilogy of the southern North Sea Basin., In: Hambrey, M.J., Christoffersen, P., Glasser, N.F., Hubbard, B.P. (Eds.), Glacial Sedimentary Processes and Products. International Association of Sedimentologists Special Publication, pp. 203-234.

Gray, J.M., 1997. The origin of the Blakeney Esker, Norfolk. Proceedings of the Geologists Association $108,177-182$.

Hamblin, R.J.O., Moorlock, B.S.P., Rose, J., 2000. A new glacial stratigraphy for eastern England. Quaternary Newsletter 92, 35-43.

Hamblin, R.J.O., Moorlock, B.S.P., Rose, J., Lee, J.R., Riding, J.B., Booth, S.J., Pawley, S.M., 2005. Revised Pre-Devensian glacial stratigraphy in Norfolk, England, based on mapping and till provenance. Geologie en Mijnbouw 84, 77-85.

Harris, C., Williams, G., Brabham, P., Eaton, G., McCarroll, D., 1997. Glacitectonized quaternary sediments at Dinas Dinlle, Gwynedd, North Wales, and their bearing on the style of deglaciation in the Eastern Irish Sea. Quaternary Science Reviews 16, 109-127.

Hart, J.K., 1990. Proglacial glacitectonic deformation and the origin of the 'Cromer Ridge' push morraine, north Norfolk, England. Boreas 19, 165-180.

Hart, J.K., 1992. Sedimentary environments associated with glacial Lake Trimingham, Norfolk, UK. Boreas 21, 119-136.

Hart, J.K., 2007. An investigation of subglacial shear zone processes from Weybourne, Norfolk, UK. Quaternary Science Reviews 26, 2354-2374.

Hart, J.K., Boulton, G.S., 1991a. The glacial drifts of northeastern Norfolk, In: Ehlers, Juergen ; Gibbard, Philip, L ; Rose, Jim (Eds.), Glacial deposits in Great Britain and Ireland. A. A. Balkema, Rotterdam, Netherlands, pp. 233-243. 
Lee, J.R., Phillips, E., Booth, S.J., Rose, J., Jordan, H.M., Pawley, S.M., Warren, M., Lawley, R.S. 2013. A polyphase glacitectonic model for ice-marginal retreat and terminal moraine development: the Middle Pleistocene British Ice Sheet, northern Norfolk, UK. Proceedings of the Geologists' Association, 124, 753-777. PRE-PROOF ACCEPTEF MANUSCRIPT.

Hart, J.K., Boulton, G.S., 1991b. The interrelations of glacitectonic and glacidepositional processes within the glacial environment. Quaternary Science Reviews 10, 335-350.

Hart, J.K., Hindmarsh, R.C.A., Boulton, G.S., 1990. Styles of subglacial glacitectonic deformation within the context of the Anglian ice-sheet. Earth Surface Processes and Landforms 15, 227-241.

Hart, J.K., Peglar, S.M., 1990. Further evidence for the timing of the middle Pleistocene glaciation in Britain. Proceedings of the Geologists' Association 101, 187-196.

Hoare, P.G., Gale, S.J., Robinson, R.A.J., Connell, E.R., Larkin, N.R., 2009. Marine Isotope Stage 7-6 transition age for beach sediments at Morston, north Norfolk, UK: implications for Pleistocene chronology, stratigraphy and tectonics. Journal of Quaternary Science 24, 311-316.

Johnson, M.D., Benediktsson, Í.Ö., Björklund, L., 2013. The Ledsjö end moraine-a subaquatic push moraine composed of glacimarine clay in central Sweden. Proceedings of the Geologists' Association, in press.

Kjær, K.H., Larsen, E., van der Meer, J., Ingólfsson, Ó., Krüger, J., Örn Benediktsson, Í., Knudsen, C.G., Schomacker, A., 2006. Subglacial decoupling at the sediment/bedrock interface: a new mechanism for rapid flowing ice. Quaternary Science Reviews 25, 2704-2712.

Krüger, J., 1993. Moraine-ridge formation along a stationary ice front in Iceland. Boreas 22, 101-109.

Krüger, J., 1996. Moraine ridges formed from subglacial frozen-on sediment slabs and their differentiation from push moraines. Boreas 25, 57-64.

Kuriger, E.M., M, T., Motyka, R.J., Bucki, A.K., 2005. Episodic reactivation of large-scale push moraines in front of the advancing Taku Glacier, Alaska. Journal of Geophysical Research 111, F01009.

Larkin, N.R., Lee, J.R., Connell, E.R., 2011. Possible ice-rafted erratics in late Early to early Middle Pleistocene shallow marine and coastal deposits in northeast Norfolk, UK. Proceedings of the Geologists' Association, in press.

Lee, J., Phillips, E., Evans, H., Vaughan-Hirsch, D., 2011a. An introduction to the glacial geology and history of glacitectonic research in Northeast Norfolk, In: Phillips, E., Lee, J., Evans, H. (Eds.), Glacitectonics : Field Guide. Quaternary Research Association, pp. 101-115.

Lee, J.R., 2009. Patterns of pre-glacial sedimentation and glacitectonic deformation within early Middle Pleistocene sediments at Sidestrand, north Norfolk, UK. Proceedings of the Geologists' Association 120, 34-48.

Lee, J.R., Booth, S.J., Hamblin, R.J.O., Jarrow, A.M., Kessler, H., Moorlock, B.S.P., Morigi, A.N., Palmer, A.P., Riding, J.B., Rose, J., 2004. A new stratigraphy for the glacial deposits around Lowestoft, Great Yarmouth, North Walsham, and Cromer, East Anglia, UK. Bulletin of the Geological Society of Norfolk $53,3-60$. 
Lee, J.R., Phillips, E., Booth, S.J., Rose, J., Jordan, H.M., Pawley, S.M., Warren, M., Lawley, R.S. 2013. A polyphase glacitectonic model for ice-marginal retreat and terminal moraine development: the Middle Pleistocene British Ice Sheet, northern Norfolk, UK. Proceedings of the Geologists' Association, 124, 753-777. PRE-PROOF ACCEPTEF MANUSCRIPT.

Lee, J.R., Pennington, C.V.L., Hobbs, P.R.N., 2011b. Trimingham: structural architecture of the 'Cromer Ridge' push moraine and controls on landslide geohazards, In: Phillips, E.R., Lee, J.R., Evans, H.M. (Eds.), Glacitectonics - Field Guide. Quaternary Research Association, Pontypool, pp. 217-228.

Lee, J.R., Phillips, E.R., 2008. Progressive soft sediment deformation within a subglacial shear zone--a hybrid mosaic-pervasive deformation model for Middle Pleistocene glacitectonised sediments from eastern England. Quaternary Science Reviews 27, 1350-1362.

Lee, J.R., Busschers, F.S., Sejrup, H.P. 2012. Pre-Weichselian Quaternary glaciations of the British Isles, The Netherlands, Norway and adjacent marine areas south of $68^{\circ} \mathrm{N}$ : implications for long-term ice sheet development in northern Europe. Quaternary Science Reviews 44, 213-228.

Lee, J.R., Rose, J., Hamblin, R.J.O., Moorlock, B.S.P., Riding, J.B., Phillips, E., Barendregt, R.W., Candy, I., 2011c. The glacial history of the British Isles during the Early and Middle Pleistocene : implications for the long-term development of the British Ice Sheet, In: Ehlers, J., Gibbard, P.L., Hughes, P.D. (Eds.), Quaternary glaciations : extent and chronology. Elsevier, pp. 59-74.

Lee, J.R., Rose, J., Riding, J.B., Moorlock, B.S.P., Hamblin, R.J.O., 2002. Testing the case for a Middle Pleistocene Scandinavian glaciation in Eastern England: evidence for a Scottish ice source for tills within the Corton Formation of East Anglia, UK. Boreas 31, 345-355.

Lian, O.B., Hicock, S.R., Dreimanis, A., 2003. Laurentide and Cordilleran fast ice flow: some sedimentological evidence from Wisconsinan subglacial till and its substrate. Boreas 32, 102-113.

Lukas, S., Benn, D.I., 2006. Retreat dynamics of Younger Dryas glaciers in the far NW Scottish Highlands reconstructed from moraine sequences. Scottish Geographical Journal 122, 308-325.

Lunkka, J.P., 1994. Sedimentation and lithostratigraphy of the North Sea Drift and Lowestoft Till Formations in the coastal cliffs of northeast Norfolk. Journal of Quaternary Science 9, 209-233.

Lüthgens, C., Böse, M. 2011. Chronology of Weichselian main ice marginal positions in northeastern Germany. Eiszeitalter und Gegenwart Quaternary Science Journal 60, 236-247.

Matthews, J.A., McCarroll, D., Shakesby, R.A., 1995. Contemporary terminal-moraine ridge formation at a temperate glacier: Styggedalsbreen, Jotunheimen, southern Norway. Boreas 24, 129139.

Moorlock, B.S.P., Hamblin, R.J.O., Booth, S.G., Kessler, H., 2002. Geology of the Cromer district - a brief description of the geological map Sheet Explanation of the British Geological Survey. 1:50 000 Sheet 131 Cromer (England and Wales).

Mortimore, R.N., Wood, C.J., Gallois, R.W., 2001. British Upper Cretaceous Stratigraphy, Geological Conservation Review Series, No. 23. Joint Nature Conservation Committee, Peterborough.

Mortimore, R.N., 2011. A chalk revolution: what have we done to the Chalk of England? Proceedings of the Geologists' Association 1122, 232-297. 
Lee, J.R., Phillips, E., Booth, S.J., Rose, J., Jordan, H.M., Pawley, S.M., Warren, M., Lawley, R.S. 2013. A polyphase glacitectonic model for ice-marginal retreat and terminal moraine development: the Middle Pleistocene British Ice Sheet, northern Norfolk, UK. Proceedings of the Geologists' Association, 124, 753-777. PRE-PROOF ACCEPTEF MANUSCRIPT.

Nieuwland, D.A., Leutscher, J.H., Gast, J. 2000. Wedge equilibrium in fold-and-thrust belts: prediction of out-of-sequence thrusting based on sandbox experiments and natural examples. Geologie en Mijnbouw/Netherlands Journal of Geosciences 79, 81-91.

Ó Cofaigh, C., Evans, D.J.A., 2001. Deforming bed conditions associated with a major ice stream of the last British ice sheet. Geology 29, 795-798.

Pawley, S.M., 2006. Quaternary glaciations of north and west Norfolk. , Unpublished PhD Thesis. University of London., p. 453.

Pawley, S.M., 2008. The Glaven Valley (Glandford Quarry) (TG 055 415), In: Candy, I., Lee, J.R., Harrison, A.M. (Eds.), Quaternary of northern East Anglia - Field Guide. Quaternary Research Association, Edinburgh, pp. 192-203.

Pawley, S.M., Bailey, R.M., Rose, J., Moorlock, B.S.P., Hamblin, R.J.O., Booth, S.J., Lee, J.R., 2008. Age limits on Middle Pleistocene glacial sediments from OSL dating, north Norfolk, UK. Quaternary Science Reviews 27, 1363-1377.

Pawley, S.M., Candy, I., Booth, S.J., 2006. The Late Devensian terminal moraine ridge at Garrett Hill, Stiffkey valley, north Norfolk, England. Proceedings of the Yorkshire Geological Society 56, 31-39.

Pawley, S.M., Lee, J.R., Riding, J.B., Moorlock, B.S.P., Hamblin, R.J.O., Rose, J., Crofts, R.G., 2005. The stratigraphy of the Briton's Lane borehole and quarry, Beeston Regis, north-east Norfolk. Bulletin of the Geological Society of Norfolk 55, 15-42.

Pawley, S.M., Rose, J., Lee, J.R., Hamblin, R.J.O., Moorlock, B.S.P., 2004. Middle Pleistocene stratigraphy of Weybourne, north-east Norfolk, England. Proceedings of the Geologists' Association $115,22-42$.

Perrin, R.M.S., Rose, J., Davies, H., 1979. The distribution, variation and origins of pre-Devensian tills in eastern England. Philosophical Transactions of the Royal Society of London B287, 535-570.

Phillips, E., Lee, J.R., 2013. Development of a subglacial drainage system and its effect on glacitectonism within the polydeformed Middle Pleistocene (Anglian) glacigenic sequence of North Norfolk, Eastern England. Proceedings of the Geologists' Association, this volume.

Phillips, E., Lee, J.R., Burke, H., 2008. Progressive proglacial to subglacial deformation and syntectonic sedimentation at the margins of the Mid-Pleistocene British Ice Sheet: evidence from north Norfolk, UK. Quaternary Science Reviews 27, 1848-1871.

Phillips, E.R., Evans, D.J.A., Auton, C.A., 2002. Polyphase deformation at an oscillating ice margin following the Loch Lomond Readvance, central Scotland, UK. Sedimentary Geology 149, 157-182.

Preece, R.C., Parfitt, S.A., 2000. The Cromer Forest-bed Formation: new thoughts on an old problem, In: Lewis, S.G., Whiteman, C.A., Preece, R.C. (Eds.), The Quaternary of Norfolk and Suffolk: Field Guide. Quaternary Research Association, London, pp. 1-28. 
Lee, J.R., Phillips, E., Booth, S.J., Rose, J., Jordan, H.M., Pawley, S.M., Warren, M., Lawley, R.S. 2013. A polyphase glacitectonic model for ice-marginal retreat and terminal moraine development: the Middle Pleistocene British Ice Sheet, northern Norfolk, UK. Proceedings of the Geologists' Association, 124, 753-777. PRE-PROOF ACCEPTEF MANUSCRIPT.

Preece, R.C., Parfitt, S.A., Coope, G.R., Penkman, K.E.H., Ponel, P., Whittaker, J.E., 2009.

Biostratigraphic and aminostratigraphic constraints on the age of the Middle Pleistocene glacial succession in north Norfolk, UK. Journal of Quaternary Science 24, 557-580.

Reid, C., 1882. The geology of the country around Cromer. H.M.S.O, London.

Roberts, D.H., Hart, J.K., 2000. The glacial deposits of Trimingham, In: Lewis, S.G., Whiteman, C.A., C, P.R. (Eds.), The Quaternary of Norfolk and Suffolk: Field Guide. Quaternary Research Association, London, pp. 103-110.

Roberts, D.H., Hart, J.K., 2005. The deforming bed characteristics of a stratified till assemblage in north East Anglia, UK: investigating controls on sediment rheology and strain signatures. Quaternary Science Reviews 24, 123-140.

Rose, J., 2009. Early and Middle Pleistocene landscapes of eastern England. Proceedings of the Geologists' Association 120, 3-33.

Rose, J., Candy, I., Moorlock, B.S.P., Wilkinson, I.H., Lee, J.A., Hamblin, R.J.O., Lee, J.R., Riding, J.B., Morigi, A.N., 2002. Early and early Middle Pleistocene river, coastal and neotectonic processes, southeast Norfolk, England. Proceedings- Geologists Association 113, 47-68.

Rose, J., Moorlock, B.S.P., Hamblin, R.J.O., 2001. Pre-Anglian fluvial and coastal deposits in Eastern England: lithostratigraphy and palaeoenvironments. Quaternary International 79, 5-22.

Rotnicki, K., 1976. The theoretical basis for and a model of glacitectonic deformation. Quaestiones Geographicae 3, 103-139.

Scheib, A.J., Lee, J.R., Breward, N., Riding, J.B., 2011. Reconstructing flowpaths of the Middle Pleistocene British Ice Sheet in central-eastern England : the application of regional soil geochemical data. Proceedings of the Geologists' Association 122, 432-444.

Slater, G., 1926. Glacial tectonics as reflected in disturbed drift deposits. Proceedings of the Geologists' Association 37, 392-400.

Sparks, B.W., West, R.G., 1964. The drift landforms around Holt, Norfolk. Transactions of the Institute of British Geographers 35, 27-35.

Stokes, C.R., Clark, C.D., Winsborrow, M.C.M. 2006. Subglacial bedform evidence for a major palaeoice stream and its retreat phases in Amundsen Gulf, Canadian Arctic Archipelago. Journal of Quaternary Science 21, 399-412.

Straw, A., 1960. The limit of the 'Last' Glaciation in north Norfolk. Proceedings of the Geologists Association 71, 379-390.

Straw, A., 1973. The glacial geomorphology of central and north Norfolk. The East Midland Geographer 5, 333-354. 
Lee, J.R., Phillips, E., Booth, S.J., Rose, J., Jordan, H.M., Pawley, S.M., Warren, M., Lawley, R.S. 2013. A polyphase glacitectonic model for ice-marginal retreat and terminal moraine development: the Middle Pleistocene British Ice Sheet, northern Norfolk, UK. Proceedings of the Geologists' Association, 124, 753-777. PRE-PROOF ACCEPTEF MANUSCRIPT.

Thomas, G.S.P., 1984. The origin of the glaci-dynamic structure of the Bride Moriane, Isle of Man. Boreas 13, 355-364.

Thomas, G.S.P., Chiverrell, R.C., Huddart, D., 2004. Ice-marginal depositional responses to readvance episodes in the Late Devensian deglaciation of the Isle of Man. Quaternary Science Reviews 23, 85106.

Thomas, G.S.P., Chiverrell, R.C., 2007. Structural and depositional evidence for repeated ice-marginal oscillation along the eastern margin of the Late Devensian Irish Sea Ice Stream. Quaternary Science Reviews 26, 2375-2405.

van der Meer, J.J.M.E., 1987. Tills and Glacitectonics. A.A. Balkema, Rotterdam.

van der Wateren, F.M., 1985. A model of glacial tectonics, applied to the ice-pushed ridges in the Central Netherlands. Geological Society of Denmark Bulletin 34, 55-74.

van der Wateren, F.M., 1995. Structural geology and sedimentology of push moraines. Mededelingen Rijks Geologische Dienst Nr 54.

van der Wateren, F.M., 2005. Ice-marginal terrestrial landsystems: Southern Scandinavian Ice Sheet Margin, In: Evans, D.J.A. (Ed.), Glacial Landsystems. Hodder Arnold, London, pp. 166-203.

Vaughan-Hirsch, D.P., Phillips, E.R., Lee, J.R., Burke, H.F., Hart, J.K., 2011. Glacitectonic rafting of chalk bedrock: Overstrand, In: Phillips, E.R., Lee, J.R., Evans, H.M. (Eds.), Glacitectonics - Field Guide. Quaternary Research Association, Pontypool, pp. 198-216.

Vaughan-Hirsch, D.P., Phillips, E.R., Lee, J.R., Hart, J.K. 2013. Micromorphological analysis of polyphase deformation associated with the transport and emplacement of glaciotectonic rafts at West Runton, north Norfolk, UK. Boreas 42, 376-394.

Waller, R., Murton, J., Whiteman, C., 2009. Geological evidence for subglacial deformation of Pleistocene permafrost. Proceedings of the Geologists' Association 120, 155-162.

Waller, R., Phillips, E., Murton, J., Lee, J., Whiteman, C., 2011. Sand intraclasts as evidence of subglacial deformation of Middle Pleistocene permafrost, North Norfolk, UK. Quaternary Science Reviews 30, 3481-3500.

West, R.G., 1957. Notes on a preliminary map of some features of the drift topography around Holt and Cromer, Norfolk. Transactions of the Norfolk and Norwich Naturalists' Society 18, 24-29.

West, R.G., 1980. The Pre-glacial Pleistocene of the Norfolk and Suffolk Coasts. Cambridge University Press, Cambridge.

Wilson, P., 2002. Morphology and significance of some Loch Lomond Stadial moraines in the southcentral Lake District, England. Proceedings of the Geologists' Association 113, 9-21.

Wright, W.B. 1937. The Quaternary ice age (Second Edition). MacMillan and Co. Ltd, London. 
Lee, J.R., Phillips, E., Booth, S.J., Rose, J., Jordan, H.M., Pawley, S.M., Warren, M., Lawley, R.S. 2013. A polyphase glacitectonic model for ice-marginal retreat and terminal moraine development: the Middle Pleistocene British Ice Sheet, northern Norfolk, UK. Proceedings of the Geologists' Association, 124, 753-777. PRE-PROOF ACCEPTEF MANUSCRIPT.

\section{Figure Captions}

Figure 1. (a) Map showing the eastern England, the study area (box), and Anglian and Devensian ice limits (after Clark et al., 2004); (b) Small inset map showing the main topographic elements of the study area including drainage and elevated ground (+60m OD) of the 'Cromer Ridge'; (c) GISgenerated rockhead contour map for northeast Norfolk based upon borehole records showing the main study sites (capital letters).

Figure 2. (a) NextMap Digital Surface Model (DSM) of the study area showing the position of the coastline, sites referred to within the text and the distribution of; (b) hybrid geomorphological map showing the simplified geology and geomorphology including data from Sparks and West (1964), British Geological Survey $(2002,2013)$ and unpublished data.

Figure 3. (a) Schematic composite section showing the stratigraphy and structure of Gimingham Quarry, Trimingham. GQ1 - dip direction / angle of bedding planes within SZ-G2 ; GQ2 palaeocurrent directions from undeformed SZ-G3; (b) Photograph showing the bedded sands and gravels and intra-formational pendulum-shaped 'drop soil' structures. Bedding in this instance dips northwards, and forms part of the upper limb of an asymmetrical anticline which occurs in the hanging-wall of a thrust.

Figure 4. Structural reconstruction of the coastal cliff section between Trimingham and Overstrand showing five structural zones (SZ-Tr1 to SZ-Tr5) (modified from Lee et al., 2011a). This section is viewed facing the cliffs.

Figure 5. (a) Large open folds of laminated marl and silt and clay at $1100 \mathrm{~m}$ (see Figure 4), facing southeast; (b) Chevron folding developed within rhythmically-bedded silts (light laminae) and clays (dark laminae) at $1000 \mathrm{~m}$ (see Figure 4).

Figure 6. (a) Annotated photograph showing the glacitectonic rafts at Overstrand (2800m; see Figure 4) - zone SZ-Tr3, direction of stress application from right to left; note that the thrust beneath the raft in the foreground is obscured by modern beach material and several additional rafts crop-out on the adjacent foreshore; (b) Annotated photograph of isoclinal folding and detachment surfaces developed within the Bacton Green Till at 3300m (see Figure 4). Detachment surfaces and fold axes dip towards the north-northwest. Direction of stress application from right to left across photograph (north-northwest to south-southeast.

Figure 7. Southwards verging asymmetrical fold of Bacton Green Till and sand at $4250 \mathrm{~m}$ (see Figure 4) truncated by vertical diapir and sand-filled fracture.

Figure 8. Annotated photo mosaic of Weybourne Town Pit showing stacked slabs of brown sandy diamicton (Bacton Green Till) and white chalky diamicton (Weybourne Town Till) bounded by a series of sharp detachments (modified from Lee, 2003 and Evans et al., 2011).

Figure 9. Southerly-verging asymmetrical fold deforming thinly-bedded sands and silts, Walcott Till and Happisburgh Till in the core of the fold. Small-scale, southerly-directed thrusts within the core of 
Lee, J.R., Phillips, E., Booth, S.J., Rose, J., Jordan, H.M., Pawley, S.M., Warren, M., Lawley, R.S. 2013. A polyphase glacitectonic model for ice-marginal retreat and terminal moraine development: the Middle Pleistocene British Ice Sheet, northern Norfolk, UK. Proceedings of the Geologists' Association, 124, 753-777. PRE-PROOF ACCEPTEF MANUSCRIPT.

the fold developed to accommodate further shortening of the sequence. Red notebook for scale (20cm length); location TG 1509043532.

Figure 10. Deformation associated with a large chalk raft exposed in the cliff sections beneath the coastguard lookout station, Skelding Hill, sited to the west of Sheringham (TG 1476 4353).

Figure 11. Sections at Stody Pit, Holt (TG 056 345) showing tectonised sands and gravels and deformed masses of diamicton with sand and gravel inclusions.

Figure 12. Schematic cross-section orientated south to north through the 'Cromer Ridge' glacitectonic complex illustrating the main geological structures and development of the twelve structural stages (1-12).

Figure 13. Time-series model showing patterns of ice-marginal behaviour relative to glacitectonic style and substrate porewater content. Key to abbreviations: HAD - High-angle detachments; LAD / IF - Low-angle detachments / isoclinal folding; LOS - Low-angle shearing; BF - Buckle and open folding; DW - Dewatering;

Figure 14. Tentative model of ice-marginal retreat reconstructed from structural and geomorphological evidence.

Figure 15. Oblique angle view of a NEXTMAP Digital Surface Model (DSM) looking south-southeast over the Glaven Valley and Cromer Ridge showing some of the primary geomorphological elements. Those indicated are the glacitectonic features such as Muckleburgh Hill, Skelding Hill and Beeston Hill, and the 'kames' of the Glaven Valley. Also shown are the Blakeney esker and the Kelling and Salthouse outwash fans. Not named, but clearly visible is the steep crenellate slope around the western margins of the outwash fans and the northern margin of the 'Cromer Ridge', and the short valleys draining from the northern margin of the 'Cromer Ridge' to the present coastline.

\section{Table Captions}

Table 1. Tectonostratigraphic framework for the glacial succession of northeast Norfolk (Lee et al., 2011a). Showing tectonic events (A1-A6), direction of ice advance, glacitectonic signature and range of structural evidence.

Table 2. Descriptions, genetic interpretation and lithostratigraphy of lithofacies mapped within Domain 1.

Table 3. Summary table showing the principal glacitectonic stages (1-12), the geological evidence and process interpretation. 
Lee, J.R., Phillips, E., Booth, S.J., Rose, J., Jordan, H.M., Pawley, S.M., Warren, M., Lawley, R.S. 2013. A polyphase glacitectonic model for ice-marginal retreat and terminal moraine development: the Middle Pleistocene British Ice Sheet, northern Norfolk, UK. Proceedings of the Geologists' Association, 124, 753-777. PRE-PROOF ACCEPTEF MANUSCRIPT.

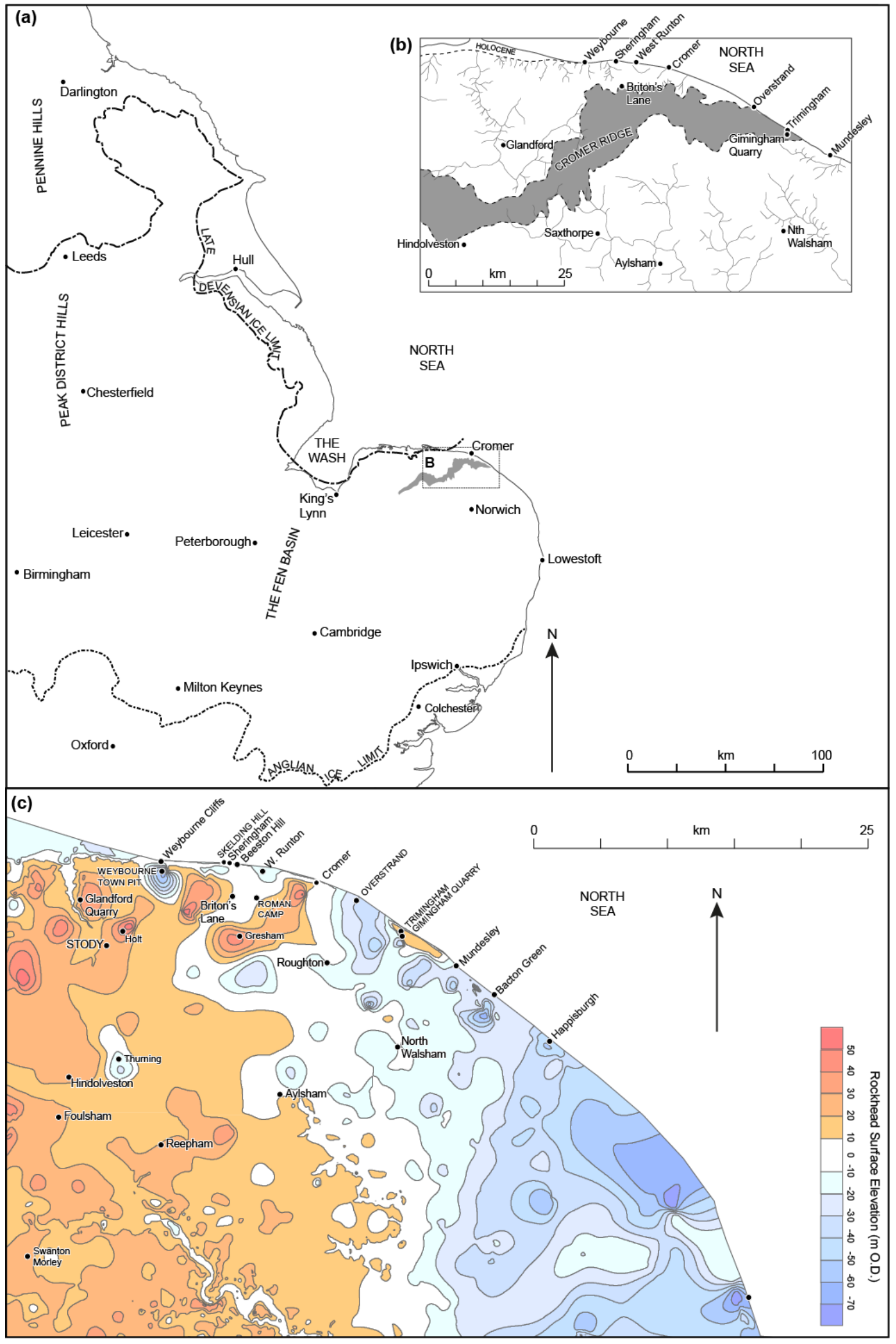

Figure 1 
Lee, J.R., Phillips, E., Booth, S.J., Rose, J., Jordan, H.M., Pawley, S.M., Warren, M., Lawley, R.S. 2013. A polyphase glacitectonic model for ice-marginal retreat and terminal moraine development: the Middle Pleistocene British Ice Sheet, northern Norfolk, UK. Proceedings of the Geologists' Association, 124, 753-777. PRE-PROOF ACCEPTEF MANUSCRIPT.
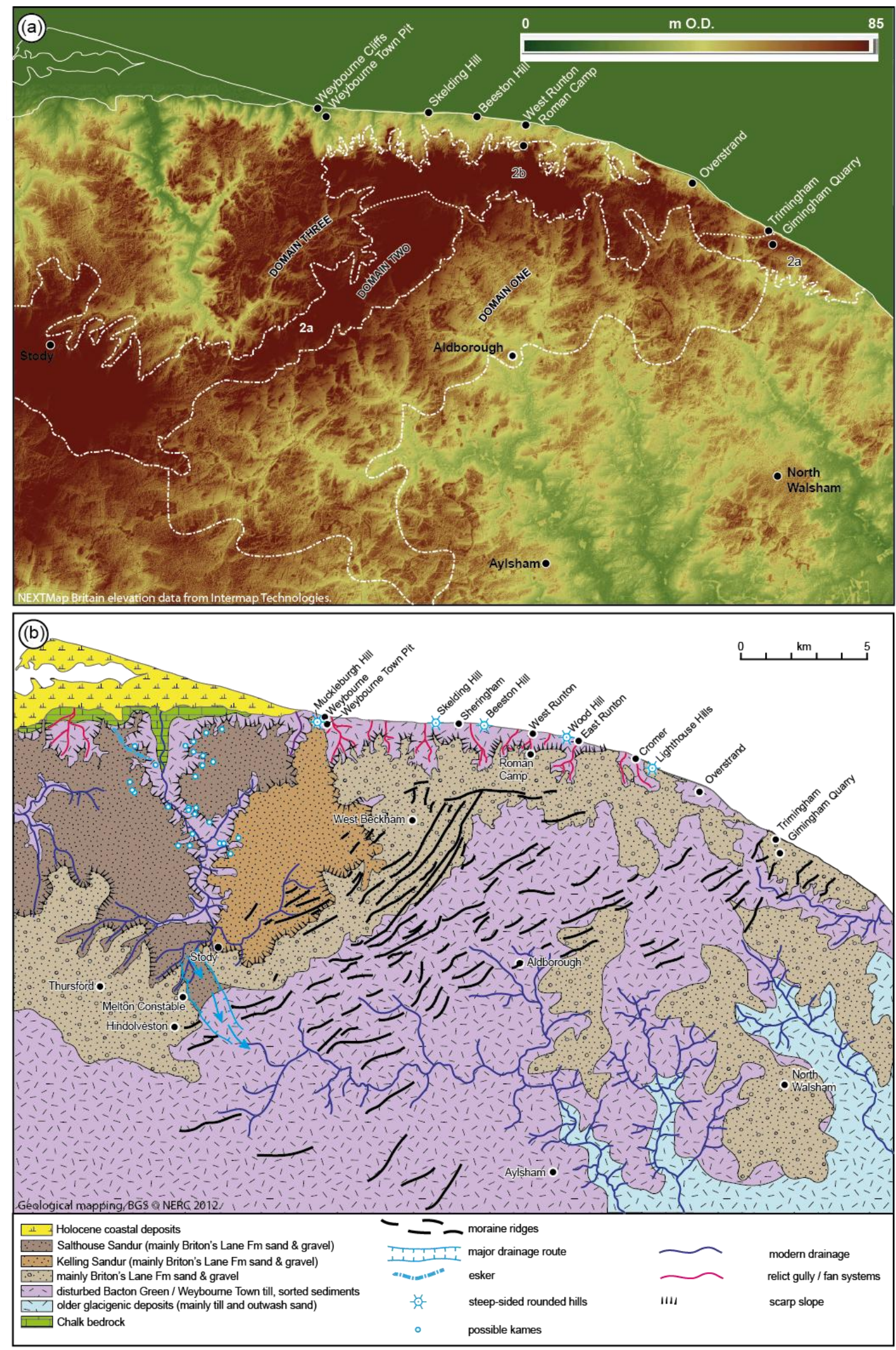

Figure 2 
Lee, J.R., Phillips, E., Booth, S.J., Rose, J., Jordan, H.M., Pawley, S.M., Warren, M., Lawley, R.S. 2013. A polyphase glacitectonic model for ice-marginal retreat and terminal moraine development: the Middle Pleistocene British Ice Sheet, northern Norfolk, UK. Proceedings of the Geologists' Association, 124, 753-777. PRE-PROOF ACCEPTEF MANUSCRIPT.
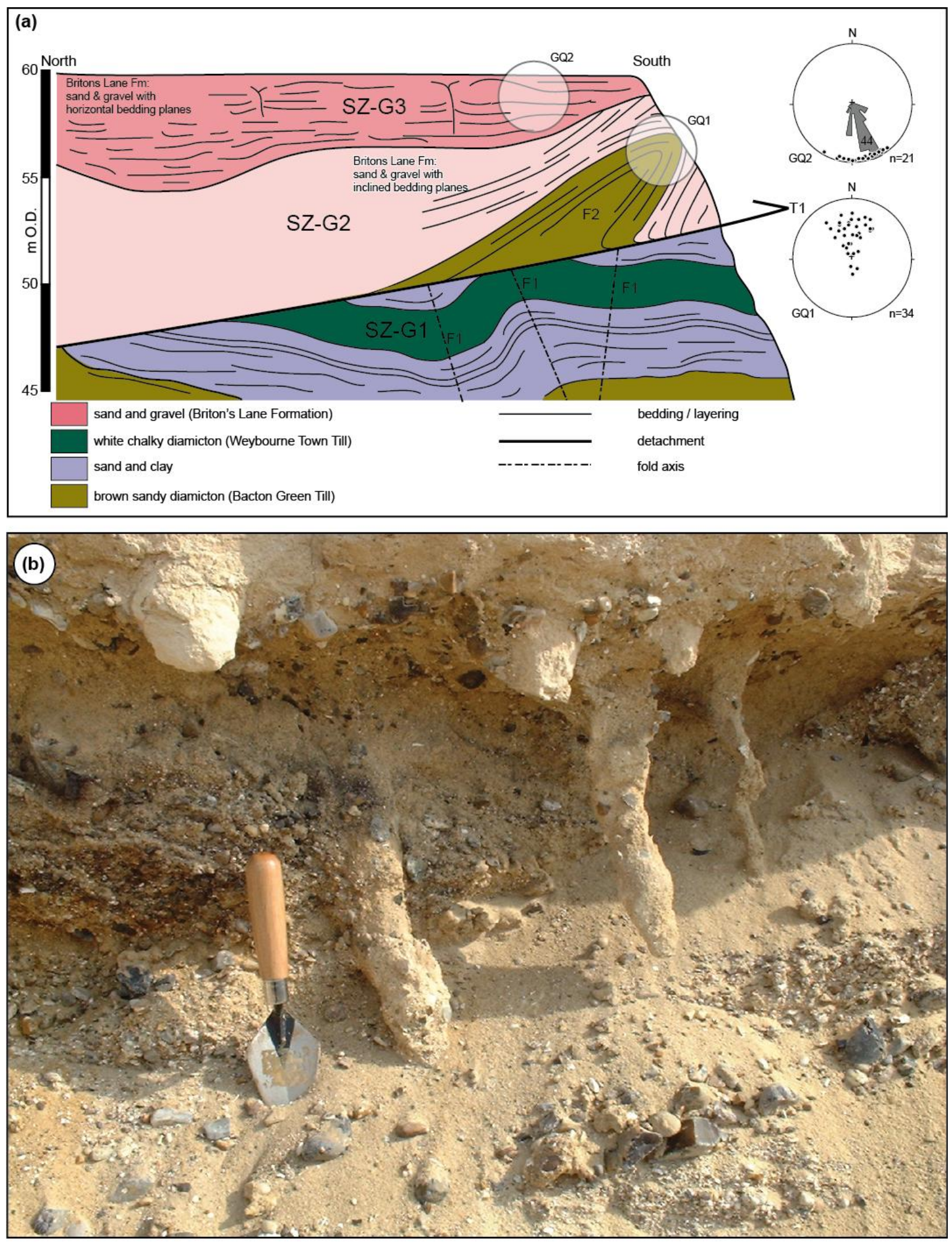

Figure 3 
Lee, J.R., Phillips, E., Booth, S.J., Rose, J., Jordan, H.M., Pawley, S.M., Warren, M., Lawley, R.S. 2013. A polyphase glacitectonic model for ice-marginal retreat and terminal moraine development: the Middle Pleistocene British Ice Sheet, northern Norfolk, UK. Proceedings of the Geologists' Association, 124, 753-777. PRE-PROOF ACCEPTEF MANUSCRIPT. 
Lee, J.R., Phillips, E., Booth, S.J., Rose, J., Jordan, H.M., Pawley, S.M., Warren, M., Lawley, R.S. 2013. A polyphase glacitectonic model for ice-marginal retreat and terminal moraine development: the Middle Pleistocene British Ice Sheet, northern Norfolk, UK. Proceedings of the Geologists' Association, 124, 753-777. PRE-PROOF ACCEPTEF MANUSCRIPT.

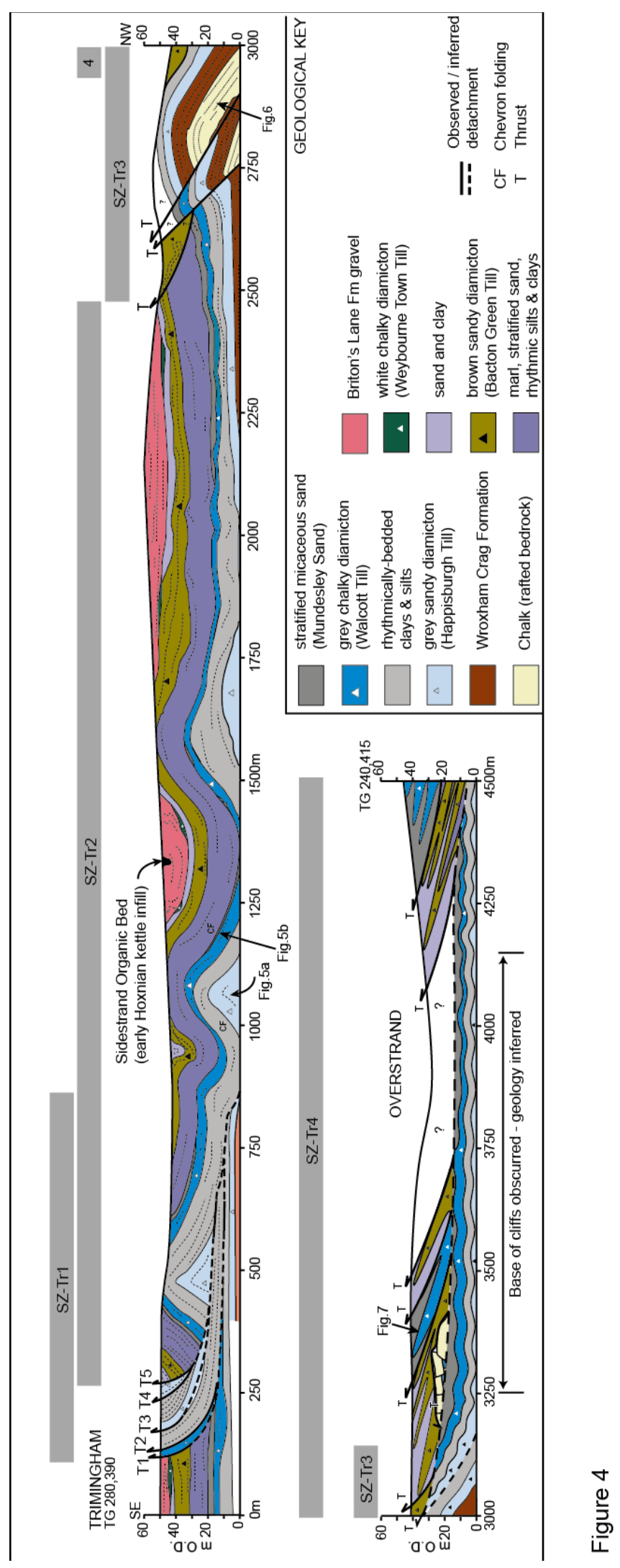


Lee, J.R., Phillips, E., Booth, S.J., Rose, J., Jordan, H.M., Pawley, S.M., Warren, M., Lawley, R.S. 2013. A polyphase glacitectonic model for ice-marginal retreat and terminal moraine development: the Middle Pleistocene British Ice Sheet, northern Norfolk, UK. Proceedings of the Geologists' Association, 124, 753-777. PRE-PROOF ACCEPTEF MANUSCRIPT.
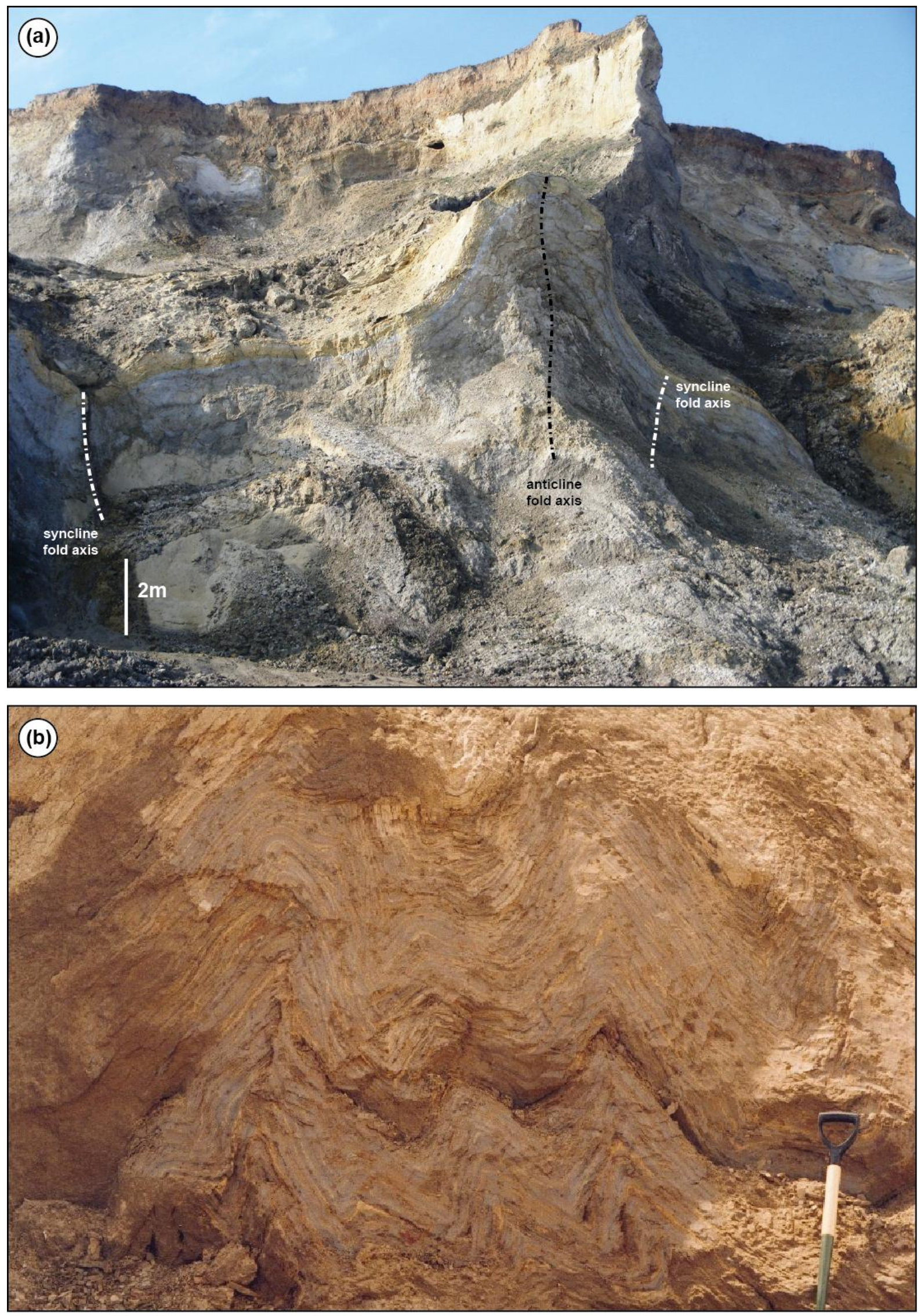

Figure 5 
Lee, J.R., Phillips, E., Booth, S.J., Rose, J., Jordan, H.M., Pawley, S.M., Warren, M., Lawley, R.S. 2013. A polyphase glacitectonic model for ice-marginal retreat and terminal moraine development: the Middle Pleistocene British Ice Sheet, northern Norfolk, UK. Proceedings of the Geologists' Association, 124, 753-777. PRE-PROOF ACCEPTEF MANUSCRIPT.
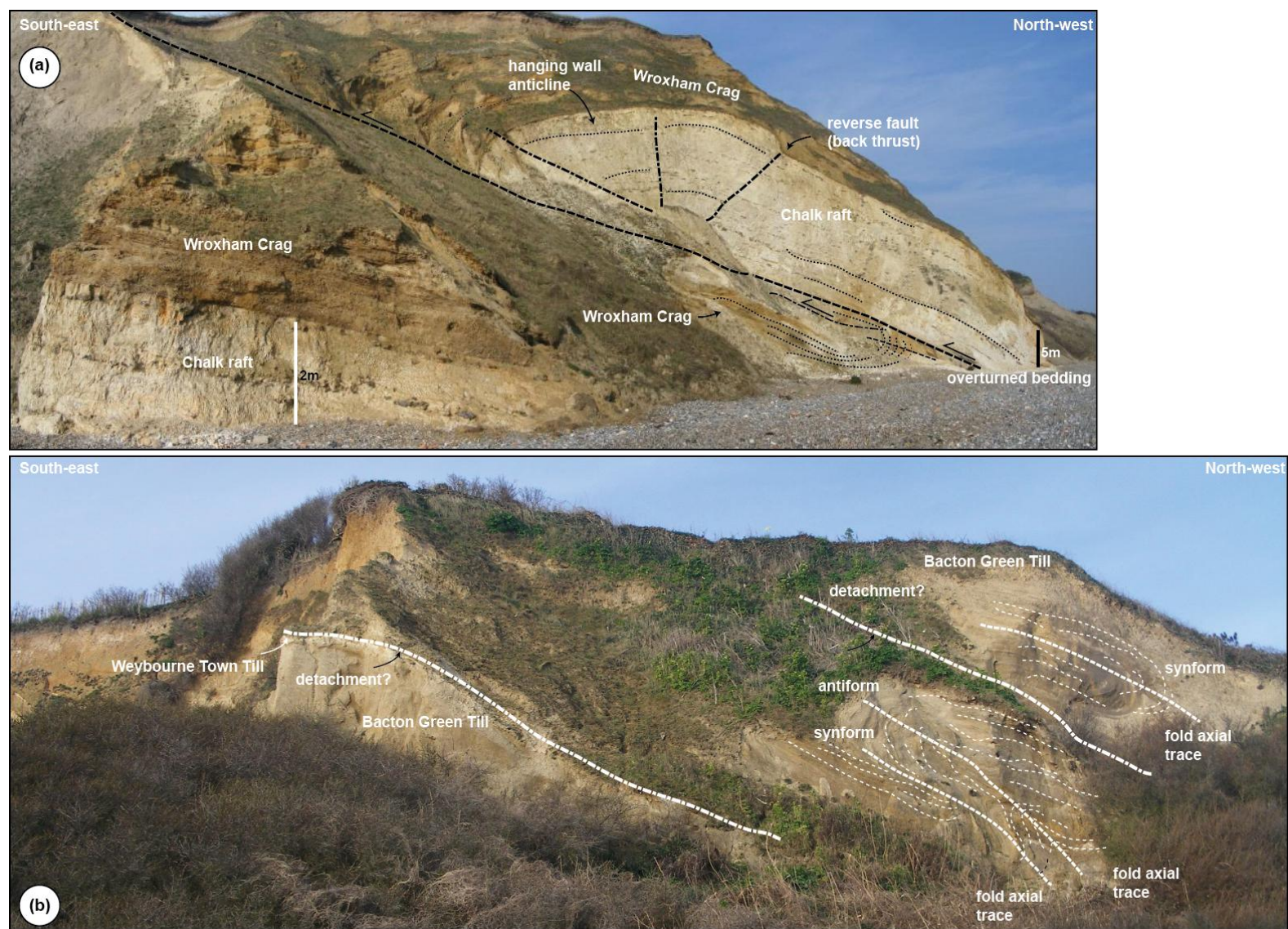

Figure 6
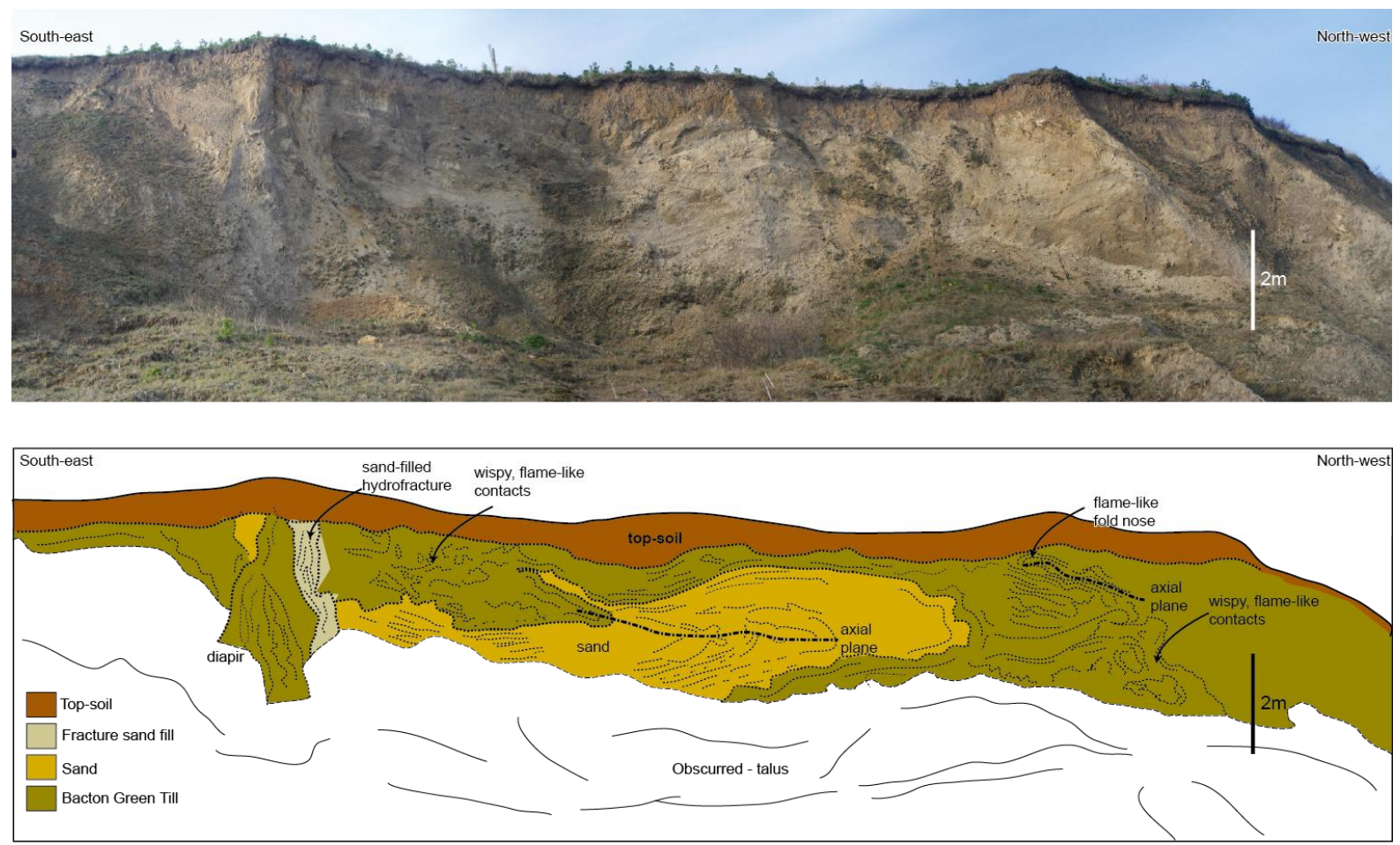

Figure 7 
Lee, J.R., Phillips, E., Booth, S.J., Rose, J., Jordan, H.M., Pawley, S.M., Warren, M., Lawley, R.S. 2013. A polyphase glacitectonic model for ice-marginal retreat and terminal moraine development: the Middle Pleistocene British Ice Sheet, northern Norfolk, UK. Proceedings of the Geologists' Association, 124, 753-777. PRE-PROOF ACCEPTEF MANUSCRIPT.

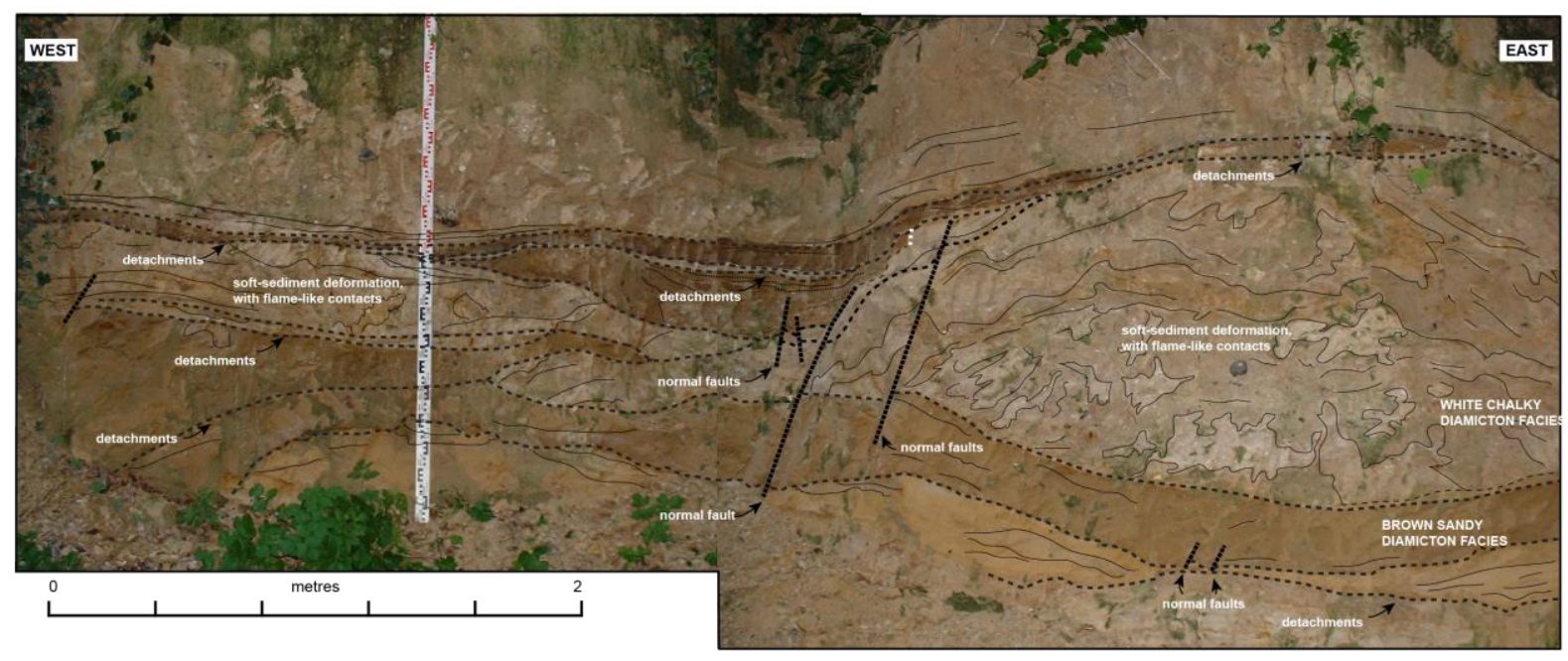

Figure 8 
Lee, J.R., Phillips, E., Booth, S.J., Rose, J., Jordan, H.M., Pawley, S.M., Warren, M., Lawley, R.S. 2013. A polyphase glacitectonic model for ice-marginal retreat and terminal moraine development: the Middle Pleistocene British Ice Sheet, northern Norfolk, UK. Proceedings of the Geologists' Association, 124, 753-777. PRE-PROOF ACCEPTEF MANUSCRIPT.
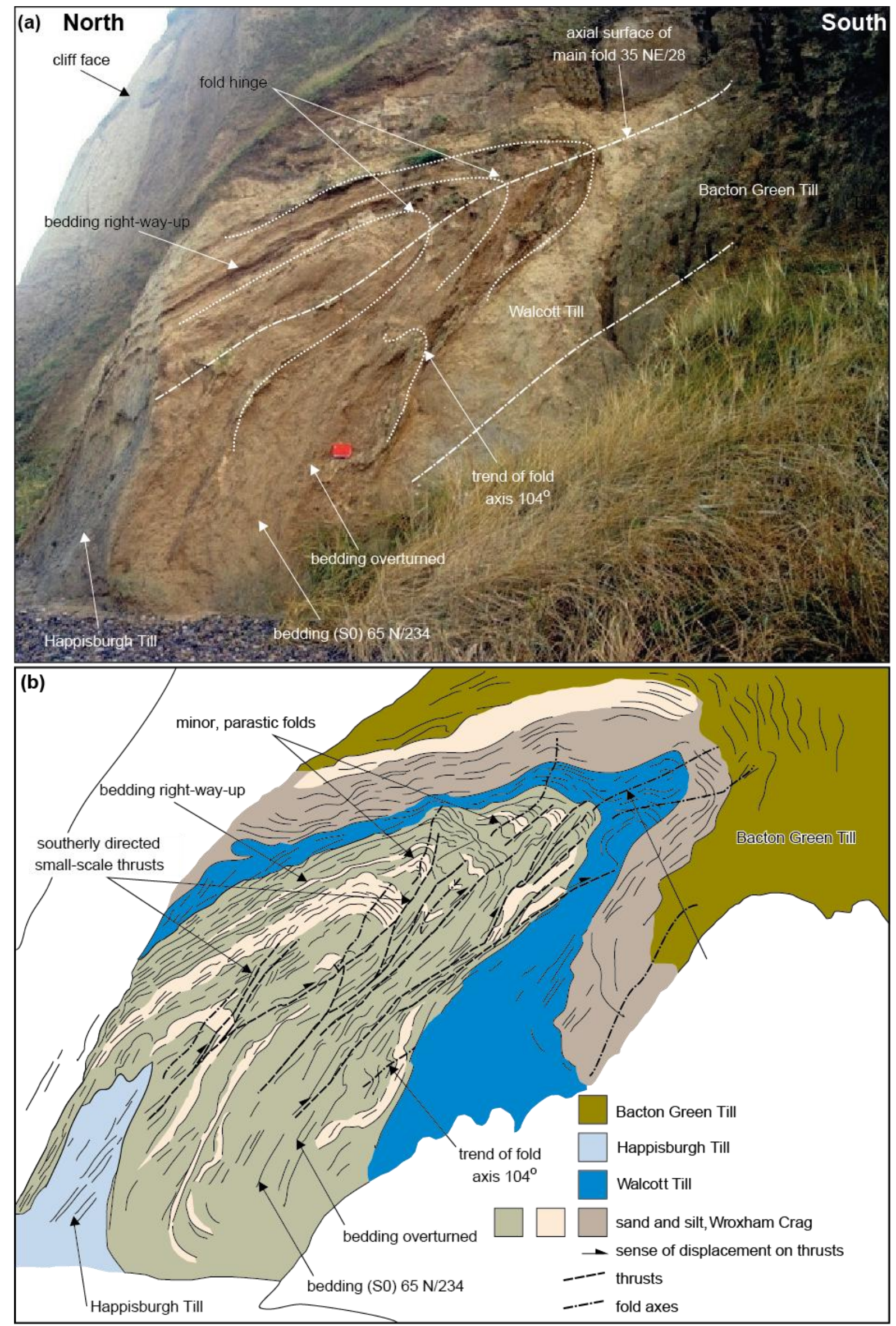

Figure 9 
Lee, J.R., Phillips, E., Booth, S.J., Rose, J., Jordan, H.M., Pawley, S.M., Warren, M., Lawley, R.S. 2013. A polyphase glacitectonic model for ice-marginal retreat and terminal moraine development: the Middle Pleistocene British Ice Sheet, northern Norfolk, UK. Proceedings of the Geologists' Association, 124, 753-777. PRE-PROOF ACCEPTEF MANUSCRIPT.

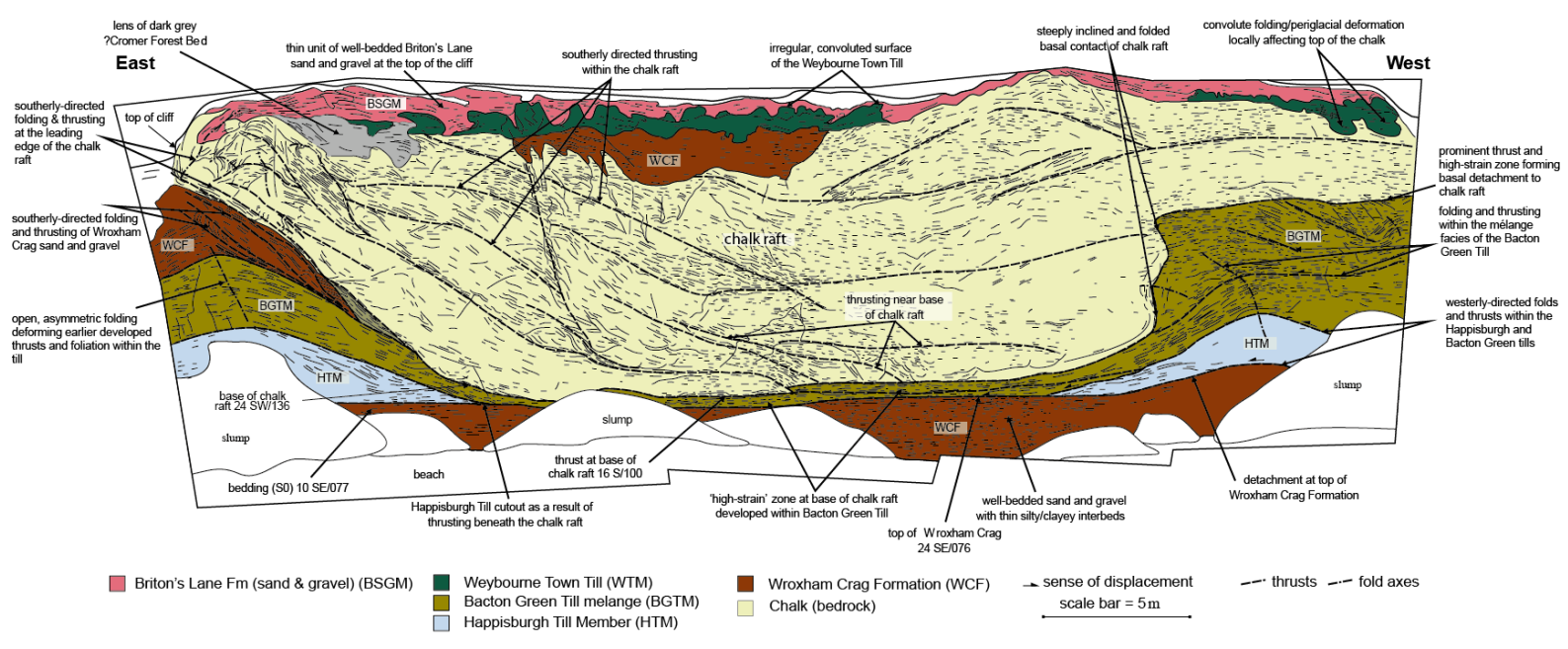

Figure 10

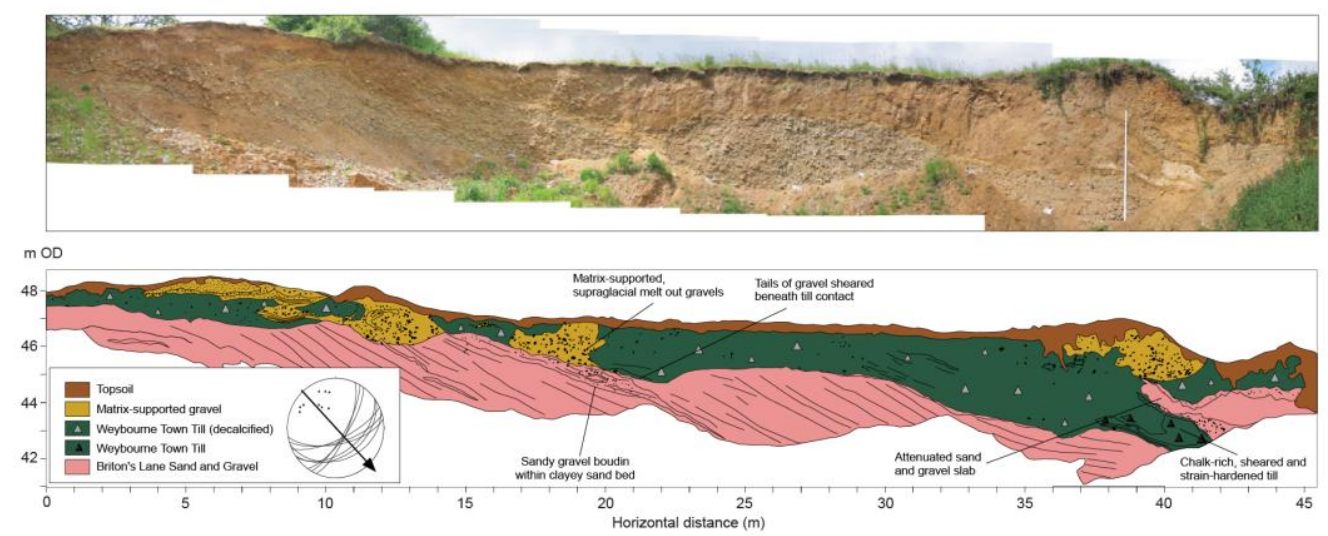

Figure 11 
Lee, J.R., Phillips, E., Booth, S.J., Rose, J., Jordan, H.M., Pawley, S.M., Warren, M., Lawley, R.S. 2013. A polyphase glacitectonic model for ice-marginal retreat and terminal moraine development: the Middle Pleistocene British Ice Sheet, northern Norfolk, UK. Proceedings of the Geologists' Association, 124, 753-777. PRE-PROOF ACCEPTEF MANUSCRIPT.

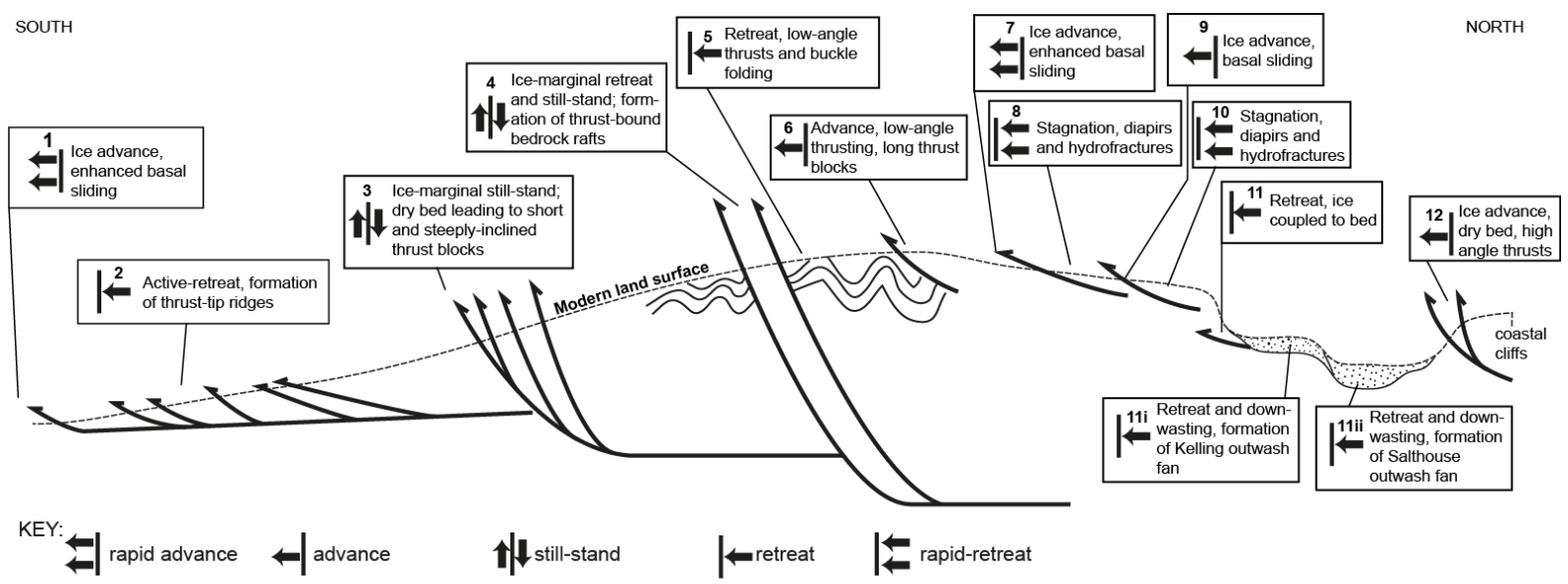

Figure 12

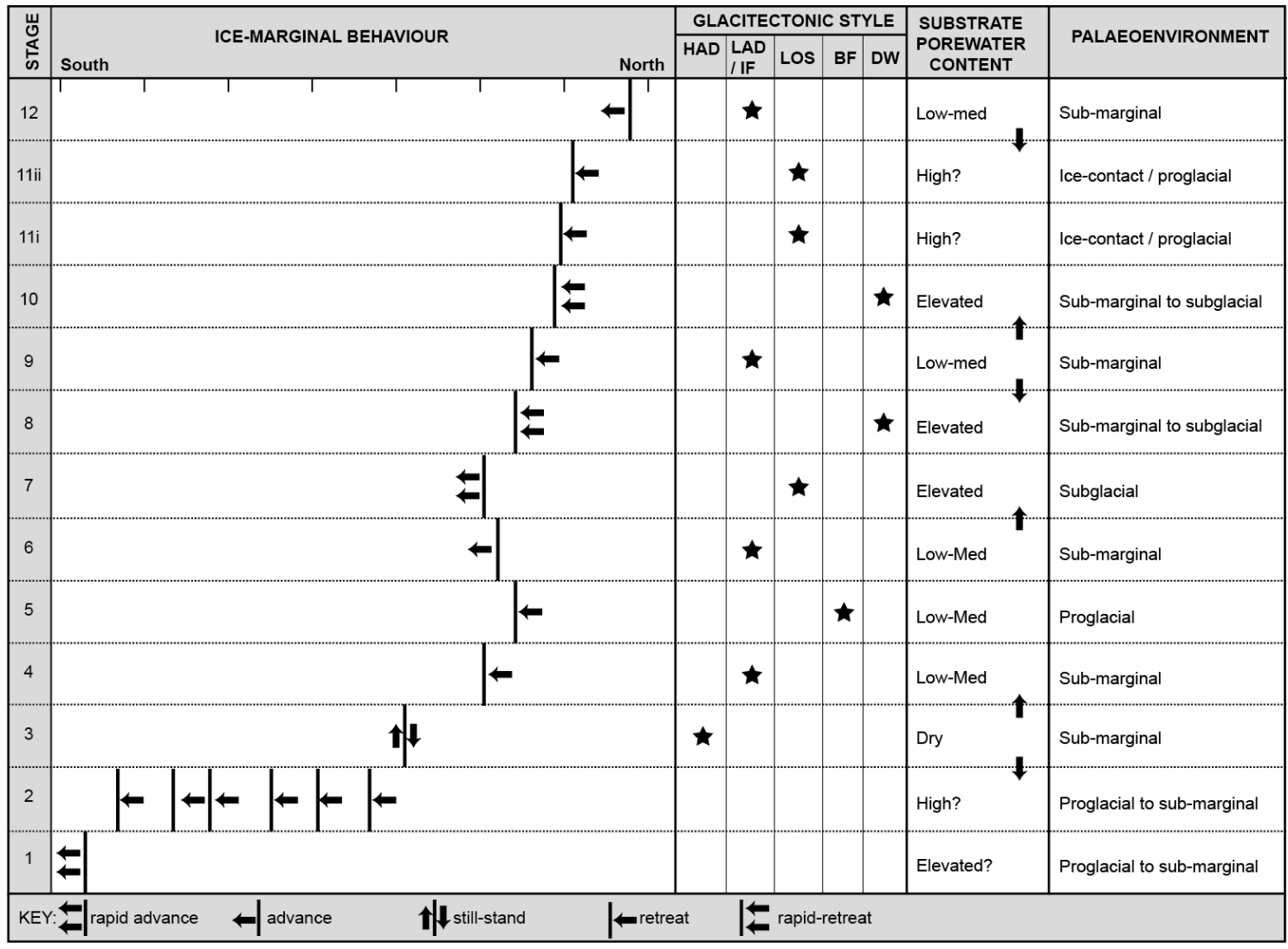

Figure 13 
Lee, J.R., Phillips, E., Booth, S.J., Rose, J., Jordan, H.M., Pawley, S.M., Warren, M., Lawley, R.S. 2013. A polyphase glacitectonic model for ice-marginal retreat and terminal moraine development: the Middle Pleistocene British Ice Sheet, northern Norfolk, UK. Proceedings of the Geologists' Association, 124, 753-777. PRE-PROOF ACCEPTEF MANUSCRIPT.
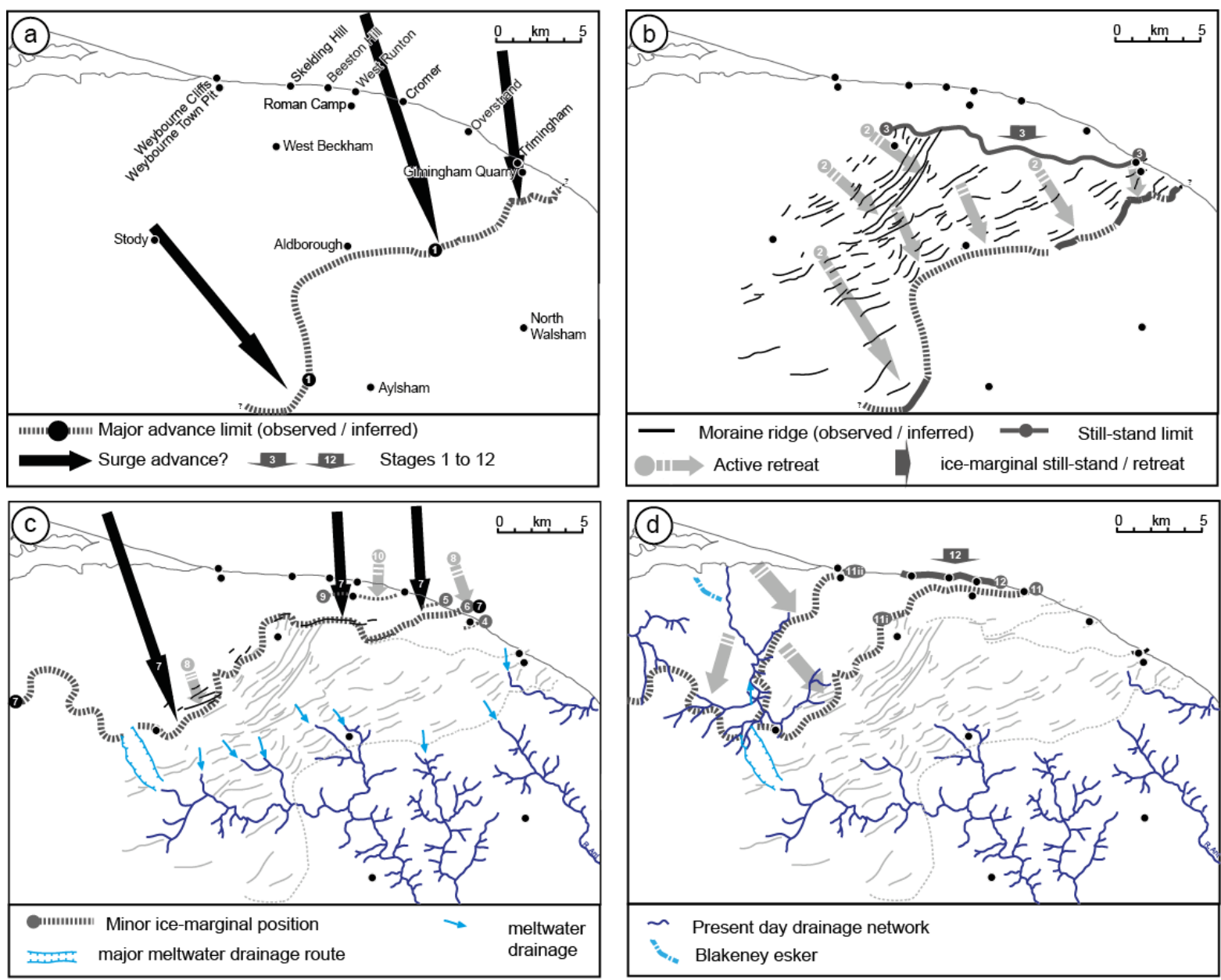

Figure 14

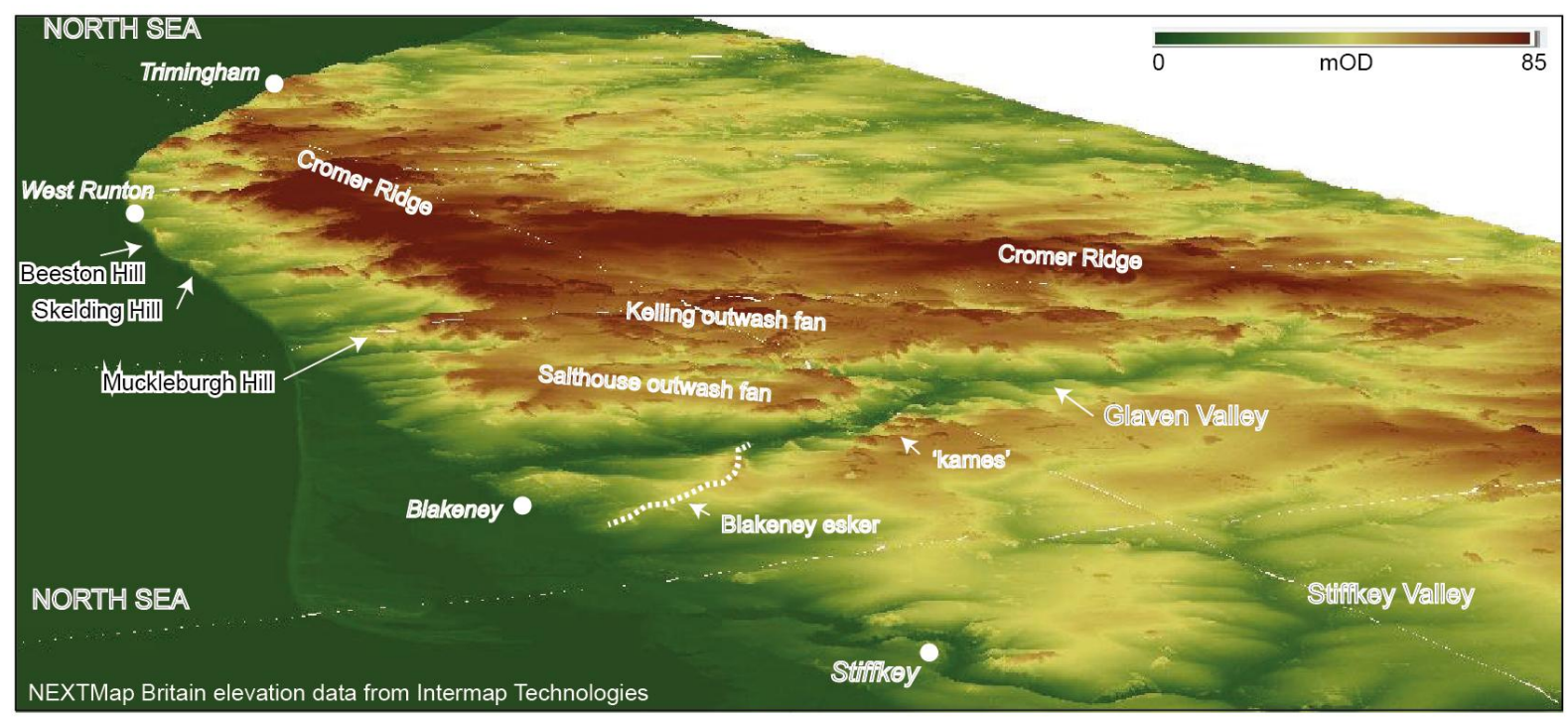

Figure 15 
Lee, J.R., Phillips, E., Booth, S.J., Rose, J., Jordan, H.M., Pawley, S.M., Warren, M., Lawley, R.S. 2013. A polyphase glacitectonic model for ice-marginal retreat and terminal moraine development: the Middle Pleistocene British Ice Sheet, northern Norfolk, UK. Proceedings of the Geologists' Association, 124, 753-777. PRE-PROOF ACCEPTEF MANUSCRIPT.

\begin{tabular}{|c|c|c|c|}
\hline EVENT & ICE ADVANCE & GLACITECTONIC SIGNATURE & STRUCTURAL EVIDENCE \\
\hline A6 & Re-advance from N & $\begin{array}{l}\text { Large-scale glacitectonism associated } \\
\text { with ice-marginal thrust-stacking; } \\
\text { Cromer Ridge and smaller ice-contact } \\
\text { features. Accretion of 'northern facies' } \\
\text { of Weybourne Town Till. }\end{array}$ & $\begin{array}{l}\text { Listric thrust faults, thrust } \\
\text { duplex structures, inverted } \\
\text { stratigraphy, large- and small- } \\
\text { scale open folding. }\end{array}$ \\
\hline A5 & Ice advance from $\mathrm{W}$ & $\begin{array}{l}\text { Large-scale glacitectonism associated } \\
\text { with subglacial deforming bed } \\
\text { processes }(<30 \mathrm{~m}) \text {; generation of } \\
\text { Bacton Green Till melange; } \\
\text { development of terminal moraine - } \\
\text { extensional basin complexes; and } \\
\text { accretion of 'western facies' } \\
\text { Weybourne Town Till. }\end{array}$ & $\begin{array}{l}\text { Sheath folding, thrusts, } \\
\text { crenulation cleavage, hanging- } \\
\text { wall anticlines, over-turned } \\
\text { folding, small-scale soft- } \\
\text { sediment deformation. }\end{array}$ \\
\hline A4 & Re-advance from $\mathrm{N}$ & $\begin{array}{l}\text { Local-scale glacitectonism associated } \\
\text { with subglacial deforming bed } \\
\text { processes }(<4 \mathrm{~m}) \text {; accretion of Bacton } \\
\text { Green Till (subglacial and } \\
\text { subaqueous). }\end{array}$ & $\begin{array}{l}\text { Diamicton homogenisation, } \\
\text { isoclinal fold noses, small-scale } \\
\text { shears, boudinage, tectonic } \\
\text { lamination, decollement } \\
\text { surfaces, small-scale soft- } \\
\text { sediment deformation. }\end{array}$ \\
\hline A3 & Ice advance from $\mathrm{N}$ & $\begin{array}{l}\text { Local-scale glacitectonism associated } \\
\text { with subglacial deforming bed } \\
\text { processes }(<4 \mathrm{~m}) \text {; accretion of Walcott } \\
\text { Till. }\end{array}$ & $\begin{array}{l}\text { Diamicton homogenisation, } \\
\text { isoclinal fold noses, small-scale } \\
\text { shears, boudinage, tectonic } \\
\text { lamination, décollement } \\
\text { surfaces. }\end{array}$ \\
\hline A2 & Re-advance from $\mathrm{N}$ & $\begin{array}{l}\text { Local-scale glacitectonism associated } \\
\text { with subglacial deforming bed } \\
\text { processes }(<4 \mathrm{~m}) \text {; accretion of Corton } \\
\text { Till. }\end{array}$ & $\begin{array}{l}\text { Diamicton homogenisation, } \\
\text { isoclinal fold noses, small-scale } \\
\text { shears, soft-sediment } \\
\text { deformation. }\end{array}$ \\
\hline A1 & Ice advance from $\mathrm{N}$ & $\begin{array}{l}\text { Local-scale glacitectonism associated } \\
\text { with subglacial deforming processes } \\
(<8 \mathrm{~m}) \text {; accretion of Happisburgh Till. }\end{array}$ & $\begin{array}{l}\text { Diamicton homogenisation, } \\
\text { isoclinal fold noses, small-scale } \\
\text { shears, boudinage, tectonic } \\
\text { lamination, decollement } \\
\text { surfaces. }\end{array}$ \\
\hline
\end{tabular}

Table 1 
Lee, J.R., Phillips, E., Booth, S.J., Rose, J., Jordan, H.M., Pawley, S.M., Warren, M., Lawley, R.S. 2013. A polyphase glacitectonic model for ice-marginal retreat and terminal moraine development: the Middle Pleistocene British Ice Sheet, northern Norfolk, UK. Proceedings of the Geologists' Association, 124, 753-777. PRE-PROOF ACCEPTEF MANUSCRIPT.

\begin{tabular}{|c|c|c|c|}
\hline No. & Lithofacies Description & Interpretation & Lithostratigraphy \\
\hline 1 & $\begin{array}{l}\text { 0.1-0.8 m thick, massive, highly- } \\
\text { consolidated, brown (10YR } 4 / 4) \text {, sandy, } \\
\text { matrix-supported diamicton; clasts }(<5 \%) \\
\text { of sub-rounded to sub-angular flint and } \\
\text { occasional chalk. }\end{array}$ & Basal till & $\begin{array}{l}\text { Bacton Green Till } \\
\text { (A4) } \\
\text { (Sheringham Cliffs Fm) }\end{array}$ \\
\hline 2 & $\begin{array}{l}0.2-2.1 \mathrm{~m} \text { thick, massive to faintly } \\
\text { stratified, light yellowish brown ( } 2.5 \mathrm{Y} \\
6 / 3) \text {, highly consolidated, matrix- } \\
\text { supported diamicton; highly calcareous } \\
\text { silt-rich matrix, abundant angular to sub- } \\
\text { rounded clasts of chalk and black flint. }\end{array}$ & Basal till & $\begin{array}{l}\text { Weybourne Town Till } \\
\text { (A5) } \\
\text { (Sheringham Cliffs Fm) }\end{array}$ \\
\hline 3 & $\begin{array}{l}\text { 0.1-0.4 m thick, massive to faintly } \\
\text { stratified clay, dark grey (10YR 4/1). }\end{array}$ & $\begin{array}{l}\text { Low energy, } \\
\text { waterlain } \\
\text { (glaciolacustrine?) }\end{array}$ & $\begin{array}{l}\text { Undifferentiated } \\
\text { (Sheringham Cliffs Fm) }\end{array}$ \\
\hline 4 & $\begin{array}{l}0.5-5.0 \mathrm{~m} \text { thick, rhythmically-bedded } \\
\text { dark grey } 10 \text { YR 4/1) clay and light } \\
\text { brownish grey (10YR 6/2) silt, occasional } \\
\text { small sand lenses. }\end{array}$ & $\begin{array}{l}\text { Low energy } \\
\text { waterlain, frequent } \\
\text { influxes of sediment } \\
\text { (glaciolacustrine? }\end{array}$ & $\begin{array}{l}\text { Undifferentiated } \\
\text { (Sheringham Cliffs Fm) }\end{array}$ \\
\hline 5 & $\begin{array}{l}\text { 0.1-0.9 m thick, poorly sorted silty sand, } \\
\text { dark greyish brown (10YR 4/2). }\end{array}$ & $\begin{array}{l}\text { Waterlain, mass } \\
\text { influx } \\
\text { (glaciolacustrine?) }\end{array}$ & $\begin{array}{l}\text { Undifferentiated } \\
\text { (Sheringham Cliffs Fm) }\end{array}$ \\
\hline 6 & $\begin{array}{l}0.05-0.3 \text { m thick, highly heterogeneous } \\
\text { admixtures of } 1 \text { and } 2 \text {, with occasional } \\
\text { seams of } 3 \text { and } 5 .\end{array}$ & Mass-flow deposit & \\
\hline 7 & 0.2-0.6 $\mathrm{m}$ thick, coarse sand and gravel. & $\begin{array}{l}\text { High energy, } \\
\text { glaciofluvial? }\end{array}$ & $\begin{array}{l}\text { Britons Lane } \\
\text { Formation }\end{array}$ \\
\hline
\end{tabular}

Table 2 
Lee, J.R., Phillips, E., Booth, S.J., Rose, J., Jordan, H.M., Pawley, S.M., Warren, M., Lawley, R.S. 2013. A polyphase glacitectonic model for ice-marginal retreat and terminal moraine development: the Middle Pleistocene British Ice Sheet, northern Norfolk, UK. Proceedings of the Geologists' Association, 124, 753-777. PRE-PROOF ACCEPTEF MANUSCRIPT.

\begin{tabular}{|c|c|c|}
\hline $\begin{array}{l}\text { Glacitectonic } \\
\text { Stage }\end{array}$ & Geological Evidence & Interpretation \\
\hline 12 & $\begin{array}{l}\text { High angle thrust blocks of chalk bedrock } \\
\text { forming Skelding Hill. }\end{array}$ & $\begin{array}{l}\text { Ice-marginal re-advance; dry } \\
\text { substrate. }\end{array}$ \\
\hline $11 \mathrm{ii}$ & Accretion of Salthouse outwash fan. & $\begin{array}{l}\text { Ice-marginal retreat, outwash } \\
\text { sedimentation within braided } \\
\text { meltwater channels. }\end{array}$ \\
\hline $11 \mathrm{i}$ & Accretion of Kelling outwash fan. & $\begin{array}{l}\text { Ice-marginal retreat, outwash } \\
\text { sedimentation within braided } \\
\text { meltwater channels. }\end{array}$ \\
\hline 11 & $\begin{array}{l}\text { Low-angle thrust stacked beds of chalky and } \\
\text { sandy diamict, Weybourne Town Pit and Stody. }\end{array}$ & $\begin{array}{l}\text { Ice-marginal retreat, localised } \\
\text { traction between ice and bed. }\end{array}$ \\
\hline 10 & $\begin{array}{l}\text { Development of diapiric structures and } \\
\text { hydrofractures at Cromer (cf. Banham, 1971). }\end{array}$ & $\begin{array}{l}\text { Stagnation, rapid de-watering } \\
\text { of sediment pile and retreat. }\end{array}$ \\
\hline 9 & $\begin{array}{l}\text { Accretion of low-angle thrust blocks and isoclinal } \\
\text { folding at the Roman Camp, West Runton. }\end{array}$ & Sub-marginal \\
\hline 8 & $\begin{array}{l}\text { Development of diapiric structures and } \\
\text { hydrofractures at Overstrand (SZ-Tr4). }\end{array}$ & $\begin{array}{l}\text { Stagnation, rapid de-watering } \\
\text { of sediment pile and retreat. }\end{array}$ \\
\hline 7 & $\begin{array}{l}\text { Superimposition of soft-sediment deformation } \\
\text { structures including recumbent and overturned } \\
\text { folding at Overstrand (SZ-Tr4). }\end{array}$ & $\begin{array}{l}\text { Readvance and ductile } \\
\text { deformation of pre-existing } \\
\text { structures within a subglacial } \\
\text { deformable bed. }\end{array}$ \\
\hline 6 & $\begin{array}{l}\text { Low-angle thrust-bound folds and nappes within } \\
\text { the upper part of SZ-Tr4 (Overstrand). }\end{array}$ & $\begin{array}{l}\text { Thin-skinned sub-marginal } \\
\text { folding and thrusting. }\end{array}$ \\
\hline 5 & $\begin{array}{l}\text { Formation of concentric buckle folds within the } \\
\text { lower part of SZ-Tr4 at Overstrand. }\end{array}$ & Ice-marginal retreat. \\
\hline 4 & $\begin{array}{l}\text { Development of open folding at Trimingham (SZ- } \\
\mathrm{Tr} 2 \text { ) and accretion of bedrock rafts at Overstrand } \\
\text { (SZ-Tr3). }\end{array}$ & $\begin{array}{l}\text { Ice-marginal still-stand during } \\
\text { retreat. }\end{array}$ \\
\hline 3 & $\begin{array}{l}\text { Development of imbricate thrust fan complex at } \\
\text { Trimingham (SZ-Tr1) and Gimingham Quarry, } \\
\text { composed of long thrust blocks aligned steeply. }\end{array}$ & $\begin{array}{l}\text { Ice-marginal still-stand and } \\
\text { 'digging-in' of the glacier snout } \\
\text { on a dry substrate; proglacial } \\
\text { formation of thrust complex } \\
\text { and syn-tectonic deposition of } \\
\text { outwash sands and gravels. }\end{array}$ \\
\hline 2 & $\begin{array}{l}\text { Small low-amplitude ridges composed of chaotic } \\
\text { inclusion or slabs of till / sorted sediments. }\end{array}$ & $\begin{array}{l}\text { Formation of small morainic } \\
\text { ridges by bulldozing and thrust- } \\
\text { stacking during active retreat. }\end{array}$ \\
\hline 1 & Southern-most small morainic ridge. & Maximum known ice extent. \\
\hline
\end{tabular}

Table 3 
Lee, J.R., Phillips, E., Booth, S.J., Rose, J., Jordan, H.M., Pawley, S.M., Warren, M., Lawley, R.S. 2013. A polyphase glacitectonic model for ice-marginal retreat and terminal moraine development: the Middle Pleistocene British Ice Sheet, northern Norfolk, UK. Proceedings of the Geologists' Association, 124, 753-777. PRE-PROOF ACCEPTEF MANUSCRIPT. 